\title{
Growth and Life Course Health Development
}

\author{
Amanda Mummert, Meriah Schoen, \\ and Michelle Lampl
}

\section{Introduction}

Physical growth is an indicator and predictor of both present and future health. Auxology, the science of physical growth, has historical roots in studies noting that poor social conditions harm children's health and well-being as reflected by their size (Tanner 1981). Subsequent epidemiologic studies linking infant size to health risks emerging later in life identify that growth is a translational embodiment of health (Barker 2012). The full spectrum of biological processes by which size accrual translates life course health development remains to be clarified. Present challenges standing in the way of better understanding the nexus between growth and health include distinctions between public health information derived from population-level epidemiologic

\footnotetext{
A. Mummert, $\mathrm{PhD}(\bowtie) \bullet$ M. Lampl, MD, PhD Department of Anthropology, Emory University, Atlanta, GA, USA

Center for the Study of Human Health, Emory University, Atlanta, GA, USA

e-mail: amanda.mummert@alumni.emory.edu

M. Schoen

Center for the Study of Human Health, Emory University, Atlanta, GA, USA

Department of Nutrition, Georgia State University, Atlanta, GA, USA
}

assessments and research evidence based on the study of growth biology of individuals; the current focus on attained size rather than the process of growth, or change in size, with a reliance on weight in lieu of length/height and body composition; and a tendency to interpret patterns derived from growth charts rather than understanding growth trajectories as they occur during individual biological processes.

Research approaches to human physical growth have largely been driven by public health efforts. Auxologically based epidemiology documented smaller size among individuals subjected to the rigors of child labor in Britain, contributing to the nineteenth-century Factory Acts aimed at regulating children's working conditions. By the twentieth century, it was recognized that such measurements were useful for population- and community-level growth surveillance. The prevalence of stunting and wasting, using age-adjusted measures of low height and weight, respectively, is currently a key component of international criteria for assessing health and well-being on a global scale (UNICEF 2014). Similarly, growth screening at an individual level became commonplace, and plotting size for age across infancy and childhood is now part of nationally and internationally endorsed guidelines for pediatric clinical medicine. Children are compared with peers of similar age and background for perspective on how they are faring relative to one another on "growth charts" produced, for example, by the US 
Centers for Disease Control and Prevention (CDC) (Kuczmarski et al. 2000) and assessed for how they should be growing under optimal circumstances, as proposed by the World Health Organization (WHO) (WHO MGRS 2006). It is important to note that these assessments actually compare size, an indication of how much growth has occurred previously, but do not provide information on growth itself as represented by the pathway taken to achieve current size (Lampl and Thompson 2007) and are often mistakenly assumed to provide details of growth biology (Lampl 2012a). Growth is an emergent process at the individual level; trajectories of growth in height, weight, and body composition offer a phenotypic reflection of the complex interactions between macro- and microlevel processes that influence life course health development.

This chapter reviews environmental and biological factors that influence physical growth, concentrating primarily on gestation through early childhood which temporally sets the stage for disease risk in later life (Barker et al. 2013). First, we describe how growth is fundamentally an emergent process reflecting the embodiment of a complex network of social, biological, and environmental interactions. Here we assess how the diversity of body size and shape reflects developmental plasticity that is evolutionarily and historically influenced. Second, we describe the importance of timing for growth biology and briefly discuss theoretical frameworks that leverage auxological research. Third, we describe macro- and micropathways affecting growth in a global perspective. Fourth, we reflect upon data and methodological challenges for understanding how attained size and/or growth rate predicts life course health development, including issues of validity and actionable clinical recommendations. Finally, we consider approaches for future research and policies to advance the science of growth biology as it may contribute to improvements in human health across the life course.

\section{Growth Is an Emergent Process}

As a record of individual health experiences, the process of growth reflects many of the life course health development principles presented by Halfon and Forrest (2017). The process of human growth unfolds as a complex adaptive system (Holland 1992). Increases in size across time occur as nodally mediated interactions among multiple pathways, reiteratively changing in response to novel environmental inputs (Lampl 2009). This sensitivity to changing conditions enables a wide bandwidth of pathways by which individuals actually grow. Variability in growth patterns is an evolutionarily robust strategy for the fundamental goal of transforming one cell to a fully functional and reproductively capable organism, necessary for preservation of the species. The human body emerges through growth (increases in size) and maturation (acquisition of adult features) as an expression of molecular and physiological processes with developmental time specificity for organ construction and functional pathway regulation.

This is well illustrated by the growth of the skeleton. Skeletal growth expresses a chronobiological program whereby length/height accrual occurs through discontinuous, aperiodic saltatory spurts at long bone growth plates, intermittently punctuating durations of no growth (Lampl et al. 1992; Noonan et al. 2004) within a speciesspecific maturational time frame until final height is achieved (e.g., several decades for humans). The mechanism(s) driving episodic growth saltations, permitting skeletal growth to emerge from a stasis period, remains to be discovered. This pulsatile system of growth increments, proceeding with variability in amplitude and frequency, is the underlying complex adaptive system (Lampl and Johnson 1998). This is the mechanism by which individual growth trajectories vary in response to reiterative readings of the environment as "novel surroundings," interpreted as 
macro- and micropathways following the life course health development terminology proposed by Halfon and Hochstein (2002). Similar complex cellular interactions and environmental exposures govern the expansion and distribution of adipose tissue depots (Ibrahim 2010), which influence weight and fat mass accrual across the life course. Growth has a cadence, with facultative processes providing for plasticity within the bounds of critical or sensitive periods, leading to a final adult form that summarizes biological events across developmental time.

Advances in skeletal biology research have expanded an appreciation of the complex system that regulates the timing and progression of skeletal growth. Initial studies described long bone length accrual as a system controlled by simple "condition/action" commands directed by growth hormone $(\mathrm{GH})$ effects on the cartilaginous growth plate (Isaksson et al. 1982). Research in the following decades demonstrated that bone growth represents the outcome of multiple nodes of cellular communication orchestrated by $\mathrm{GH}$ and insulin-like growth factor 1 (IGF-1) interacting with factors such as thyroid hormones, sex steroids, and inflammatory cytokines (Sederquist et al. 2014; Wit and Camacho-Hubner 2011). These are not simply additive processes but rather work as feedback loops among pathways by which the skeleton integrates environmental information. In this way, genetic predispositions underlying bone growth are influenced by environmental signals that culminate in adult stature. For example, inputs from both brain- and gutderived serotonin act directly on the bone building and remodeling cells, osteoblasts, and osteoclasts, respectively, providing several paths by which skeletal growth reflects the interaction between nutrition and the social environment (Karsenty and Yadav 2011).

The outcome of this multiple input system is a wide bandwidth of growth patterns and considerable phenotypic variation in human height, from the very tall Dutch to the relatively short Mbuti peoples (Eveleth and Tanner 1990). Intergenerational changes, with taller offspring by comparison with their parents, are not uncommon accompaniments to public health improvements in many different environments and ecologies (Malina 2004). For example, among four cohorts born between 1883 and 1999 in Sweden, adult stature increased on average by $16 \mathrm{~cm}$ (6.3 inches) for males and $8 \mathrm{~cm}$ (3.2 inches) for females (Stinson 2012). Recent secular increases have occurred predominantly in developing regions as compared to developed regions (Cole 2003), reflecting contemporary changes in determinants of growth such as improved nutrition, reduced disease burden, and social conditions. Examples include the increased height among children and adolescents from Oaxaca, Mexico, between the 1970s and late 2000s that are attributed to improvements in local infrastructure in the form of healthcare services, dietary variety, and potable water (Malina et al. 2011). Nonetheless, these individuals remain significantly shorter than individuals born and raised in the United States, with a high proportion of stunting in relation to WHO growth standards. This may reflect intergenerational and/or genetic effects, including maternal size, as well as sustained challenges from the local environment on final height. Indeed, a trend toward taller individuals is not a universal historic trend, and stature attenuation, stagnation, or even decline has been observed among women in the poorest countries (Subramanian et al. 2011). As childhood height predicts longevity (Barker et al. 2011), these growth-based differences have important implications for life course health development.

Secular changes are not reserved for height; high-income countries saw increases in body mass index [BMI - height $(\mathrm{m}) /$ weight $(\mathrm{km})^{2}$ ] beginning in the 1970s. These trends came to characterize middle- and low-income countries globally (Swinburn et al. 2011) with approximately 1.46 billion adults overweight (BMI $\geq 25)$ as of 2008 (Finucane et al. 2011). Increasing overweight and obesity prevalence extends to children and adolescents, with only some plateaus emerging (Olds et al. 2011). These types of 
morphological fluctuations are not new and have been described as signaling epidemiologic or nutritional transitions, whereby historical changes in ecological and sociocultural factors alter major risks facing human health (Harper and Armelagos 2010; Omran 1971; Popkin et al. 2012) that are expressed through alterations in growth and body size. Overall, interpopulation variability in height and weight is a sensitive reflection of diversity in local conditions (Paciorek et al. 2013).

\section{The Importance of Timing for Health and Well-Being}

Humans have a relatively lengthy period of physiologic immaturity among mammals, presenting a window of environmental sensitivity with the potential for considerable phenotypic plasticity (Johnston 1998). While experiences in the juvenile and adolescent phases affect developmental trajectories (Cameron and Demerath 2002), by all present accounts, the earliest growth periods are most formative for growth and life course health development. Indeed, the effects of malnutrition and chronic infectious diseases occurring during infancy and early childhood can have greater predictive power for height than genetics (Delgado et al. 1982; Martorell et al. 1977). This reflects the cadence of development in which attained height results from bone growth during critical periods in early life. By contrast, weight and body composition are responsive to shortterm effects from nutrition and physical activity across the life course.

The body grows through cumulative cell division, expansion, and reorganization. While gene regulatory networks lay down the basic human body form and function (Peter and Davidson 2011), functional pathways and organs are modified by intrinsic biological mechanisms influenced by maternal conditions. The term programming mechanisms has been utilized to describe factors that lead to permanent changes in physiology during critical or sensitive periods and have long-term implications for life course health development (Ben-Shlomo and Kuh 2002).
Programming opportunities start prior to conception. Obese women, for example, accumulate metabolites such as insulin, lactate, and triglycerides within their ovarian follicles, increasing the likelihood that their offspring will develop certain diseases, such as diabetes, cardiovascular disease, or cancer later in life (Robker et al. 2009). Subsequently, trophoblast cell invasion of the uterine wall and remodeling of the uterine spiral arteries are among the earliest critical moments of development as the pathway for fetal blood supply is established (Gude et al. 2004). Thereafter, the expansion of the functional placenta takes on a mediating role. Once regarded as merely a filter protecting the fetus from environmental insults (Susser and Stein 1994), the placenta is now recognized as a fundamental source of significant life course health programming (Barker and Thornburg 2013).

Numerous studies document the importance of early life for health, with intrauterine growth predicting outcomes spanning multiple domains. One of the most clarifying human data sets comes from a group of individuals exposed to famine conditions at different periods of pregnancy in Amsterdam during World War II. Biomarkers of chronic disease progression document more prominent atherogenic lipid profiles among the offspring of mothers with early exposure (Roseboom et al. 2000), while the odds of microalbuminuria, a prognostic marker for kidney disease, are greater among those with mid-gestational exposure (Painter et al. 2005b), and glucose intolerance has been associated with late exposure (Ravelli et al. 1998). These effects were not only confined to the generation who were fetuses during the war but also extended to the children of those individuals. Among women exposed to malnutrition as fetuses late in gestation, their own pregnancies were characterized by increased twinning (Painter et al. 2008b) as well as excess perinatal mortality (Lumey and Stein 1997). While birth weight in the second generation was not associated with maternal gestational exposure to famine, length at birth was decreased, and ponderal index was increased, even when adjusting for other maternal characteristics (Painter et al. 2008a), suggesting persistent effects. Several 
sex-specific morbidity and mortality trends have also emerged. For men, early gestational exposure was associated with obesity at age 19 (Ravelli et al. 1976), although this risk attenuated by age 50 (Ravelli et al. 1999). Meanwhile, among women, early exposure was associated with higher BMI at age 50 (Ravelli et al. 1999), and the relative severity of famine exposure increased the hazard ratio for type 2 diabetes by 51\% (van Abeelen et al. 2012a). The age at sequelae emergence also reflects sex-specific interactions. While earlier studies documented no association between mortality risk and famine exposure (Painter et al. 2005a; Roseboom et al. 2001), a reexamination of the aging cohort 7 years later found sex-specific mortality trends (van Abeelen et al. 2012b; Ekamper et al. 2015).

The evidence from the Dutch Hunger Winter cohort draws attention to the importance of timing for life course health development in two key ways. First, the timing of famine exposure had discrete effects during specific developmental windows for organ development. For example, kidney nephron number increases slowly from gestational weeks 10 to 18 , after which proliferation increases rapidly until formation permanently terminates at about the 32nd week (Gasser et al. 1993; Hinchliffe et al. 1991). Individuals with famine exposure within this discrete window display biomarkers of glomerular impairment, and in utero exposure to the famine increased the odds of hypertension at age 59 by 1.44 (Stein et al. 2006). This was not the case among individuals exposed only during midgestation (Roseboom et al. 1999). Thus, timespecific famine exposure may have inhibited glomerular expansion leading to long-term kidney function inefficiencies and subsequent increased blood pressure, a contributor to multiple chronic conditions documented among this cohort (Roseboom et al. 2011). With the recognition of previously unidentified disease sequelae later in life (van Abeelen et al. 2012b; Ekamper et al. 2015), these data also demonstrate the importance of long-term longitudinal research for investigating life course health development. Risk profiles reflecting aberrant growth during earliest development may not emerge for decades and may continue to be expressed in future generations.

The data from the Dutch Hunger Winter cohort identify an array of health outcomes sourced to a common exposure and validate the robust literature, encompassing both historical and contemporary prospective cohorts, that relates birth weight and/or the tempo of postnatal weight and length accrual as mechanistically linked to adult health and well-being. These findings have been reviewed elsewhere (Barker 2012; Gluckman et al. 2008) and include altered risk for a wide range of chronic morbidities such as type 2 diabetes and metabolic syndrome (Eriksson et al. 2006), cardiovascular disease (Kelishadi and Poursafa 2014), hypertension and kidney disease (Barker et al. 2006), chronic obstructive lung disease (Duijts et al. 2014), and osteoporosis (Cooper et al. 2006), in addition to heightened risks for multimorbidity (Hack 2006) and early mortality (Barker et al. 2011). Surveys of the literature have also identified long-term associations between poor early life conditions and social capital indicators, ranging from cognitive ability (Shenkin et al. 2004) and behavioral traits suggestive of poor mental health (Schlotz and Phillips 2009) to differential employment and wages (Barker et al. 2005).

Most of the research included in these reviews, however, was not privy to information about specific exposures and/or exposure timing comparable to the temporally defined events endured by the Dutch Hunger Winter cohort. This has led to a series of methodological critiques, including remarks noting the limited incorporation of considerations stemming from cumulative life course adversity (Elford et al. 1991), the use of an inductive approach without attempts at refutation (Paneth and Susser 1995), and concerns that the results of some studies reflect an explanatory framework-guided statistical modeling influence on outcomes, in alignment with "Simpson's paradox" (Weinberg 2005; Tu et al. 2005).

The life course health data have also fueled controversy stemming from evolutionary perspectives on modern disease trends, with Ellison and Jasienska (2007) arguing for the necessity to develop and test alternative hypotheses in order 
to investigate if the reported outcomes actually represent inherent biological constraints, pathologies, or adaptations. Similarly, Hanson and Gluckman (2014) encourage distinction between outcomes of what they term developmental conditioning, namely, that some effects are potentially adaptive in the sense of conferring a fitness advantage (e.g., epigenetic influences on fetal growth rates and placental perfusion), whereas others are pathophysiological or nonadaptive and arise through exposure to environmental attributes that are novel in comparison to human evolutionary time (e.g., human-produced endocrine disruptors that alter neural and behavioral development). These critiques reflect the depth and breadth to which the research community has embraced the importance of early life experiences for health and have led to several distinct, yet interrelated, explanatory frameworks, including the life course health development framework.

\section{$4 \quad$ Explanatory Frameworks for Understanding Early Growth and Later-Life Health Outcomes}

The impact of maternal conditions and the greater environment on offspring health has been long recognized. For example, scientific description of "critical" and "sensitive" periods can be traced to at least the 1920s and 1930s in studies documenting temporal specificity between exposures and physiological and behavioral attributes (Lorenz 1935; Stockard 1921). Epidemiological interest in factors driving adult mortality, including an appreciation for how changes to child welfare would have long-term benefits emerging in adulthood, was similarly present by at least the 1930s (Kermack et al. 1934). Later, the severe birth defects resulting from thalidomide exposure, a drug prescribed to pregnant women to reduce morning sickness in the late 1950s and 1960s (McBride 1961), provided an unfortunate example of fetal sensitivity that demonstrated the phenotypic effects of environmental insults. From this earlier work, multiple disciplines and frameworks have emerged to describe and theorize why and how developmental outcomes in the pre- and perinatal period affect later health outcomes.

Epidemiologists, for example, have utilized and developed the life course health development framework which identifies health as a function of environmental, social, psychological, and biological factors that interact across the life span, which can more generally be described as macroand micropathways (Halfon and Hochstein 2002). This framework draws attention to the correlation between macropathways fundamental to growth biology. For example, poverty and food insecurity have shared outcomes, including growth faltering (Cook and Frank 2008). In other epidemiologic literature, macropathways have been described as social determinants of health (Wilkinson and Marmot 2003), although here poverty was specifically excluded because increased gross national product and income equality are not consistently tied to reduced neonatal and infant mortality or increased life expectancy (Regidor et al. 2012). Biological embedding, meanwhile, emphasizes how systematic differences in social environments alter developmental processes and physiological attributes that influence health, well-being, learning, and behavior across the life course (Hertzman 2012). In this framework, gradients of exposure within three domains of child development (physical, socialemotional, and language-cognitive) reflect the timing and persistence of early social experiences and correspond to how the signature unfolds as latent, pathway, and cumulative effects.

Multiple disciplines, ranging from neuroendocrinology to anthropology, have embraced the concept of allostatic load to explain how one's cumulative life experience, including perceived and actual challenges to physiology, contributes to health outcomes. Allostasis is the process of achieving homeostasis by modulating physiological systems or behaviors and is considered an adaptive short-term response to acute stressors (McEwen and Wingfield 2003). Allostatic overload occurs when an individual's adaptive range is exceeded after chronic stress exposure. This is expressed as a differential risk for poor physical and mental health outcomes resulting from, for example, chronic activation of the hypothalamic- 
pituitary-adrenal (HPA) axis (Worthman 2009; Krieger and Smith 2004). Using this framework, Worthman and Panter-Brick (2008) constructed a measure of allostatic load to assess how psychosocial stress and markers of developmental adversity, including physical growth, are mediated by individual-level factors among Nepali children. They observed that village residence posed a greater risk for low height-for-age $Z$-scores compared to both homeless and squatter boys, who reported lower psychosocial stress, typically considered protective of health. Further, their measure of allostatic load consistently distinguished between the three living conditions, suggesting that mixed methods approaches combining biomarkers, field epidemiology, and ethnography are important for contextualizing developmental research.

The notion of a mismatch between the environment in which the human body evolved and that in which we live today has been invoked to explain the recent rise in chronic disease prevalence (Gluckman and Hanson 2006), a concept that was earlier an underlying feature of several developmental biology frameworks. The idea of diseases emerging across time as legacies from once useful genes, later interacting with novel environments, was originally tagged as the thrifty gene hypothesis (Neel 1962). A similar concept appeared decades later as the thrifty phenotype hypothesis (Hales and Barker 2001) to describe the emergence of modern disease patterns as reflections of discontinuities between what the human body expects from the environment and what the environment delivers (Nesse 2005). A more recent proposal defined predictive adaptive responses $(P A R s)$ as anticipatory adaptive phenotypic traits that offer a fitness advantage between the postnatal period and onset of reproductive competence, such as increased insulin sensitivity that promotes accelerated growth and adipose tissue deposition to potentially improve survivorship in early life (Gluckman et al. 2005; Hanson and Gluckman 2014). While a PAR may increase reproductive fitness in the short term, it could have longer-term consequences for the health of individuals if the phenotype is not aligned with the later-life environment. The association between maternal vitamin $\mathrm{D}$ deficiency and poor perinatal outcomes is a compelling example of how modern health trends might be explained within these "mismatch" frameworks. Vitamin D deficiency among ethnic minority women with darker complexions living in northern latitudes is highly prevalent (Prentice 2008) and has been interpreted as reflecting the intersection of biological adaptations to limit ultraviolet radiation exposure and sociocultural veiling practices (Jablonski and Chaplin 2000), which in combination have been posited to underlie heightened risks for maternal/ infant health including low birth weight (LBW), gestational diabetes, and preeclampsia (Aghajafari et al. 2013). As vitamin D is essential for skeletal growth and bone strength (DeLuca 2004) and influences chronic disease risk (Souberbiellea et al. 2010), low maternal vitamin D may alter offspring initial bone set points and increase the risk of osteoporosis and skeletal fractures across the life span.

Understanding that early growth is a fundamental source of life course health is the result of considerable work describing the developmental origins of health and disease (DOHaD), launched by the geographic and social epidemiologic work of David Barker (2012), and building on previous insights of the importance of maternal and environmental conditions for body size and growth (e.g., McKeown and Record 1954; Ounsted 1965) and their relationship to later disease risk (e.g., Forsdahl 1977; Gennser et al. 1988). Recognizing that intrauterine growth and growth rates in infancy and childhood serve as cumulative markers of early life experience, several longitudinal cohorts have provided data across multiple generations from both Europe (e.g., Boyd et al. 2013; Wijnstok et al. 2013) and developing regions globally (e.g., Adair et al. 2011; Richter et al. 2007) documenting that birth weight and growth trajectories predict a number of later-life health outcomes, including type 2 diabetes, stroke, and osteoporosis (Barker 2012). This framework has been a primary driver in stimulating the discovery of mechanisms that permanently alter metabolism, physiology, or the structure of growing organs and, thus, result in a predisposition to adult health risks (Barker and 
Thornburg 2013). Research supporting the macro- and micropathways involved in these relationships are emerging.

\section{$5 \quad$ Macropathways Affecting Growth Outcomes Across the Life Course}

While family studies document heritability as a determinant of height and BMI (Silventoinen et al. 2010), phenotypic variability among individuals as they grow is more influenced by the local context into which one is born and subsequently develops than by one's genome (Frongillo et al. 1997). Whether environmental influences are additive or synergistic is difficult to ascertain (Bart van der Worp et al. 2010), but growth and its outcome, size, are clearly biosensors of population health (Tanner 1981; Cameron 2007). Historical studies concentrated on environmental challenges associated with insufficiency (e.g., malnutrition) and resultant size reduction, while present populations face overabundance, mirroring increasing ill-health associated with overweight globally. External factors influencing physical growth reflect national-, state-, community-, and individual-level resource availability (Eveleth and Tanner 1976; 1990). Here we focus on a selection of macropathways that influence growth with implications for subsequent life course health.

\subsection{Nutrition and Feeding Practices}

Among the best-documented pathways affecting growth outcomes and life course health development are maternal nutrition during preconception, gestation, and postnatal infant feeding practices (Ramakrishnan et al. 2012; Wiedmeier et al. 2011). Maternal nutritional well-being, either in terms of her actual intake or as summarized by her own size and body composition, influences her offspring's health through effects on fetal growth and birth size (Barker et al. 2013). Fetal nutritional adequacy is often assessed by proxy, based on maternal weight and weight gain during pregnancy, which positively predict fetal limb, head, and abdominal growth (Thame et al. 2012; Neufeld et al. 2004) as well as subcutaneous fat at birth (Yajnik et al. 2003): within the normal range, larger mothers have larger babies. Maternal diet during pregnancy likewise affects neonatal outcomes, such that lower average birth weights have been reported following pregnancies among British women who consumed high carbohydrate intake in early pregnancy and those who consumed less dairy and meat protein in late pregnancy (Godfrey et al. 1996). Similarly, proportionate birth weight increases were found in relation to maternal protein consumption across gestation in South Australia (Moore et al. 2004). A meta-analysis of 29 randomized controlled trials - conducted in both low- and high-income countries - found that maternal nutritional supplementation reduced the incidence of LBW and interventions that increased macronutrient intake increased average birth weight and length (Gresham et al. 2014). Maternal overnutrition as assessed by obesity, in contrast, is associated with both small and large size at birth with consequences for life course metabolic health (Schmatz et al. 2010; Dabelea et al. 2000).

Infant and postnatal feeding clearly alter the tempo of growth with size outcomes: low weight is generally indicative of short-term nutritional insufficiency, while shorter length/stature reflects cumulative exposures to undernutrition. Specific effects of breastfeeding on growth and size are mixed, with greater life course gains in weight and length/height associated with longer exclusive breastfeeding durations in developing countries, particularly among boys (Juez et al. 1983; Ricco et al. 2001), while smaller size is found among exclusively or predominantly breastfed as opposed to formula-fed infants in some environments (Saleemi et al. 2001; Victora et al. 1998). This may reflect differences in breast milk composition (Gidrewizc and Fenton 2014), secondary to maternal physiology and/or local ecology. A pooled analysis of outcomes in developed countries from nearly 300,000 infants represented in 28 studies found that breastfeeding in early infancy reduces the risk of obesity among older children and adults (Owen et al. 2005). Similar 
results have been obtained from studies in developing countries where, for example, breastfeeding was inversely associated with BMI among young adolescents in Iran (Kelishadi et al. 2007). These outcomes may reflect the benefit of breastfeeding for self-regulation beyond the content of the milk itself ( $\mathrm{Li}$ et al. 2010). After the weaning transition, during which growth often falters (McDade and Worthman 1998), feeding patterns and dietary choices continue to affect growth. For example, sweetened beverage intake (Fiorito et al. 2009) and energy-dense diets low in fiber and high in fat (Johnson et al. 2009) in childhood predict later adiposity and obesity.

\subsection{Psychosocial Stress}

Animal models document that psychosocial stress influences on physical growth begin at the earliest ages. The human experience of psychosocial stress is more difficult to quantify due to the complexity of isolating factors empirically. One pathway is mediated by effects on birth size: both acute and chronic maternal psychosocial stress increase the risk for intrauterine growth restriction (IUGR) and LBW (Beydoun and Saftlas 2008), including a dose/ response decrease in infant birth weight associated with serial prenatal stress events (Wadhwa et al. 1993). Chronic stress has been found to explain a high proportion of birth weight disparities among Latinas, African Americans, and Caucasians (Strutz et al. 2014). Specific sources of stress associated with infant size include parental job displacement (Lindo 2011), while maternal distress and depression have been linked to increased risk of LBW, as reported among both urban Brazilian (Rondo et al. 2003) and rural Pakistani (Rahman et al. 2007) mothers, respectively. Conversely, social support during pregnancy is protective; birth weight buffering occurs as social network size increases among white and Latina women from Utah (Dyer et al. 2011) and with higher perceived social support among pregnant displaced women in Thailand (Sanguanklin et al. 2014).

Various data sources document that psychosocial stress experienced during infancy and childhood has lasting effects on health. Family conflict doubled the odds of short stature at age 7 among a British cohort (Mongomery et al. 1997), and physical growth deficits escalate with increasing time in institutional care and age at adoption (DobrovaKrol et al. 2008). These outcomes tend to persist regardless of socioeconomic status (SES) (Peck and Lundberg 1995). Stress from geopolitical circumstances is also significant, as shown by the reduced growth across infancy and childhood accompanying segregation and the concomitant living conditions among black South Africans (Cameron 2003). Similarly, shorter adult height has been associated with the total number of lifetime displacement experiences among Laotian adult refugees (Clarkin 2012).

\subsection{Acute and Chronic Disease}

Life course health development also reflects direct effects from the local ecology on growth. Disease burden can exacerbate poor nutritionexpressed growth outcomes (Dewey and Mayers 2011), as demonstrated by the association between both chronic intestinal and respiratory infections and reduced stature. Chronic diarrheal disease often accompanies a failure to gain and maintain weight (Bhutta et al. 2004), with a dose/ response relationship between diarrheal days and the likelihood of stunting reported among a pooled cohort of 2-year-old children from nine prospective studies representing five developing countries (Checkley et al. 2008). Similarly, an increased risk of stunting at age two was independently predicted by both febrile respiratory infection and diarrhea history (Adair and Guilkey 1997). These are effects comparable to those documented among South African maternally HIV-infected children, who exhibit reduced length-for-age and weight-for-age $Z$-scores across the first year of life (Bobat et al. 2011).

\subsection{Altitude}

Ecological effects on birth size and subsequent growth include oxygen tension and other environmental challenges associated with living at 
varied altitudes. Compared to their low-altitude $(300 \mathrm{~m})$ counterparts, Bolivian infants born at high altitude $(3600 \mathrm{~m})$ weigh approximately $300 \mathrm{~g}$ less with a concomitant higher occurrence of IUGR (Keyes et al. 2003). Comparable differences between low- and high-altitude dwelling populations have been documented in the Himalayas (Wiley 1994) and the Rocky Mountains in the United States (Unger et al. 1988). These patterns persist across childhood and adulthood. For example, even when controlling for confounding factors like SES, the odds of stunting and underweight are significantly increased among Tibetan children living at higher altitudes (>3500 m) (Dang et al. 2008). Stunting continues to be a defining feature of children in the Peruvian highlands despite relative improvements in political and economic stability, which may impact future secular trends in the region (Pawson and Huicho 2010).

\subsection{Environmental Contaminants}

Industrialization has introduced a number of environmental contaminants, including but not limited to air pollution, lead, and polychlorinated biphenyls (PCBs) that have observable effects on skeletal growth and body composition outcomes, particularly through gestational exposure (Schell et al. 2006). Ambient air pollution is related to birth weight and IUGR (Sram et al. 2005), as seen among Californian (Salam et al. 2005) and rural Guatemalan cohorts (Thompson et al. 2011). Lead exposure has effects on multiple dimensions of body size. Among a New York cohort, infants of mothers with mid-gestational lead levels $\geq 3 \mu \mathrm{g} / \mathrm{dL}$ had reduced head circumference at 6 and 12 months, and weight-for-length and upper arm circumference-for-age $Z$-scores declined as maternal lead concentrations increased (Schell et al. 2009). Additionally, maternal consumption of PCBcontaminated fish or cooking oil has been linked to reduced birth weight near Lake Michigan (Fein et al. 1984) and shortened stature and reduced lean mass in older children from Taiwan (Guo et al. 1994).

\subsection{Income, Social Status, and Educational Attainment}

Social inequalities have long been tied to differential health outcomes, including growth trajectories, in studies using various indicators of SES, including parental education or income (Wilkinson and Pickett 2006). A systematic review found a consistent relationship between socioeconomic disadvantage and an increased risk for adverse birth outcomes, particularly among racial/ethnic minorities (Blumenshine et al. 2010). Among British infants, a mean height deficit of approximately $1.5 \mathrm{~cm}$ was observed among those whose mothers had low education levels, with comparable results obtained in relation to occupation and father's education (Howe et al. 2012). Social standing and body composition show similar associations, irrespective of ethnicity. For example, among both white and black South African children, being in the lowest SES tertile at birth was associated with decreased lean mass index [LMI - lean mass $(\mathrm{kg}) /$ height $\left.(\mathrm{m})^{2}\right]$ at 9 and 10 years of age, while higher current SES was associated with increased BMI (Griffiths et al. 2008). A multinational investigation conducted among 4- to 6-year-old children found location-specific associations between maternal educational attainment and offspring height and obesity. While among children in the United States, Sweden, and China higher maternal education was associated with taller child height, it was only protective against obesity in American and Swedish children (Lakshman et al. 2013). In addition to formal maternal education, instruction on topics such as feeding strategies has been associated with increased length gain in a cluster randomized controlled trial conducted among rural Indian families (Vazir et al. 2013), suggesting that education is a tangible target for improving global well-being (Simkhada et al. 2008).

\subsection{Healthcare Resources and Urban/Rural Status}

Healthcare resources are unequally distributed globally, with additional significant differences in access to care in urban versus rural locations 
that contribute to growth outcomes. Lavy et al. (1996) found that increased access to healthcare services had positive benefits on both height-forage and weight-for-height in rural Ghana. They estimated that if rural children had access to health services equal to those received by urban children (11.5 h per week), their life span would increase by $9.3 \%$, and health disparities would become nearly absent. Likewise, Frankenberg et al. (2005) reported that children born into a village with a midwife in Indonesia were on average $1.5 \mathrm{~cm}$ taller than their peers at age 4; the effect was greatest among children with mothers who had less education relative to her community which suggests that the midwife was increasing access to perinatal care. Similar differences are observed in developed countries. In the United States, $21.6 \%$ of rural children in eastern Kentucky were low in height-for-age, and 13\% met the criteria for stunting (Crooks 1999), while Lutfiyya et al. (2007) found that rural residency in the United States increased the odds of overweight or obesity by $25 \%$ among children over 5 . In contrast, Martorell et al. (2000) found rural residence protective of overweight and obesity among children 12-60 months of age in a survey of developing nations. These differences reflect the underlying complexity of these indicators, particularly in relation to global nutrition transitions (Popkin et al. 2012).

\section{Micropathways from the Cell to the Organism}

The preceding section described relationships between socio-structural conditions and body size with examples intended to demonstrate that similar outcomes in terms of size stem from disparate sources, whether assessed by income, the burden of stress or disease, or environmental contaminants. Mechanisms or micropathways that enable these factors to become embodied are beginning to be elucidated. Unlike the observational studies conducted among global human populations, much of the mechanistic work is based on findings from animal models and celllevel research.

\subsection{Cell-Level Controls}

The tempo of fetal and postnatal growth fundamentally reflects coordinated cellular events, influenced by nutrition and overall energetic balance (Yanagida et al. 2011). Among humans, celllevel underpinnings of morphologic features may underlie the link between decreased birth weight and growth velocity among Kenyan infants with maternal diets low in animal protein, zinc, and iron (Neumann and Harrison 1994), for example. Here, protein restriction may be operating to downregulate cell cycling and, together with iron deficiency, upregulating apoptotic genes (Swali et al. 2011), resulting in reduced size. One of the more enigmatic human health challenges is a relationship between poor gestational nutrition and obesity risk (Ong and Dunger 2002). Animal models suggest cell differentiation pathways as contributory. Reduced size observed through the first 12 weeks of life among rats with gestational, but not postnatal, protein restriction can reflect delayed mesenchymal stem cell differentiation, as well as modulation of osteoblast proliferation and differentiation by IGF-1 and GH (Oreffo et al. 2003). Subsequently, by 16 weeks of age, the gestationally protein-restricted rats' growth rates were significantly increased by comparison with control animals, suggesting a "catch-up" response during the postnatal period. Similarly, maternal protein restriction was associated with both increased preadipocyte proliferation in 28-day rat pups (Bol et al. 2008) and obesity in adult rats (Bol et al. 2009). Hence, maternal diet may translate to offspring size by multiple pathways from cell cycle control to gene transcription with longterm consequences on cell size and differentiation potential (Fowden et al. 2006).

\subsection{Hormonal, Inflammatory, Metabolic, and Immune Signaling}

A broad range of hormones, immune cells, and inflammatory compounds influence growth outcomes through signaling cascades of fetal and maternal origin. Maternal stress illustrates one 
circuit. Chronic maternal HPA axis activation, and subsequent cortisol production, moderates IGF-1 and GH exposure (Cooper 2004), central pathways in skeletal biology (Hall 2005). Fetoplacental $11 \beta$-hydroxysteroid dehydrogenase type 2 (11 $\beta$-HSD2), which catalyzes the metabolism of active cortisol and corticosterone to more inert forms, turns up and down the volume on potential fetal glucocorticoid exposure. This permits fetal levels to be lower than maternal levels (Mastorakos and Ilias 2003), a potentially protective effect. The efficiency of $11 \beta$-HSD2 is variable, however, and reduced $11 \beta-\mathrm{HSD} 2$ activity is associated with IUGR and LBW (Kajantie et al. 2003; Mericq et al. 2009).

Maternal diet modulates metabolic hormones, with effects on fetal skeletal growth and body composition. In a rat model, maternal dietary protein restriction was associated with decreased concentrations of maternal IGF-1, insulin, and leptin, accompanied by downregulated placental amino acid transporters, decreasing nutrient delivery to the fetus with subsequent LBW (Jansson et al. 2006). Conversely, obese human mothers with high BMI and elevated leptin levels showed upregulation of placental amino acid transporters associated with increased birth weight (Jansson et al. 2008).

Maternal influences on postnatal growth continue via the immunostimulatory effects of breastfeeding. Breast milk contains growth signaling compounds, ranging from leptin to inflammatory cytokines such as TNF- $\alpha$ and IL-6, with effects on skeletal, fat, and lean mass accrual. Increasing breast milk leptin levels have been associated with lower infant weight gain through the sixth postnatal month (Schuster et al. 2011) and increasing IL-6 levels with lower infant weight-for-length $Z$-score and fat mass at 1 month of age (Fields and Demerath 2012), effects that attenuate at later ages (Brunner et al. 2015). The leptin and IL-6 effects on weight gain and fat mass accrual may reflect influences on appetite and/or digestive processes via gastrointestinal epithelial cell receptors (Savino et al. 2009), or changing patterns of adipocyte cell size and/or differentiation potential (Morrison and Farmer 2000).

Likewise, a wide range of common environmental exposures influences growth hormones and sex steroids. A common contaminant, lead exposure, disrupts the pituitary gland, directly attenuating the release of GH (Berry et al. 2002) and thereby diminishing skeletal growth, with indirect effects of appetite suppression (Hammond et al. 1989) reducing weight gain in rat pups. Further, pre- and postnatal lead exposure is associated with subsequent delayed menarche and alterations in body morphology across the pre- and postpubertal period (Denham et al. 2005).

\subsection{Microbiome}

Microbial communities are a significant source of metabolic influences on growth. Comparisons between germ-free and normal mice reveal that the microbiome is largely responsible for circulating metabolites (Wikoff et al. 2009), offering a mechanism by which environmental exposures have differential effects among individuals. Distinct microbiome compositions are found in the gastrointestinal tracts of monozygotic twins (Turnbaugh et al. 2010), and phylum-level differences in microbiota and bacterial diversity distinguish between obese and lean individuals within twin pairs (Turnbaugh et al. 2009). Infant microbiome colonization reflects maternal vaginal and fecal microbiota, with maternal factors including weight and pregnancy-associated weight gain altering bacterial content (Funkhouser and Bordenstein 2013). While it remains to be described, it is plausible that even the earliest of maternal-to-fetal bacterial exposure via the placental microbiome (Aagaard et al. 2014) is a source of both direct and indirect life course health development influences.

The microbiome is not static; in fact, microbial composition has been shown to be sensitive to dietary change (David et al. 2014) and antibiotic exposure (Theriot et al. 2014). In the postnatal period, microbiome content changes with the transition from breast milk to complementary food and is influenced by caretaking practices and other social environmental factors (Guarner and Malagelada 2003; Thompson et al. 2015). Bacteria that are highly efficient at processing milk oligosaccharides are abundant during early infancy, 
with the profile shifting to a more adult-like composition as weaning occurs (Koenig et al. 2011). Temporal fluctuations of the microbial diversity during infancy are highly individualized (Palmer et al. 2007) and, in comparison to adult microbiomes, exhibit more interpersonal variation in functional genes (Kurokawa et al. 2007). As these factors may influence aspects of metabolism and in turn energy availability, this variation may offer personalized pathways by which various exposures encountered across development are incorporated and reflected phenotypically in terms of body size. For example, evidence of reduced levels of Bacteroides and increased levels of Firmicutes among obese individuals in samples of both humans (Turnbaugh and Gordon 2009) and mice (Ley et al. 2005) suggests microbial contributions to weight regulation.

\subsection{Epigenetics}

The mechanisms by which environmental factors influence phenotypic outcomes during development include genetic polymorphisms involved in growth and metabolism, such as those reported for Igfl or PPAR (Dos Santos et al. 2004; Arends et al. 2002), with risks that may change across the life course via epigenetic modifications (Waterland et al. 2006). While these modifications are concentrated during gametogenesis and early embryogenesis (Vickaryous and Whitelaw 2005), the epigenome continues to be altered across the life span with known effects from nutrition and endocrine factors (Ozanne and Constancia 2007), among others. The direct effects of maternal dietary modulation on phenotype are well illustrated by the agouti mouse model in terms of both body size (Dolinoy et al. 2006) and coat color (Dolinoy 2008). Among humans, epigenotypes are influenced by health states as illustrated by the association between impaired maternal glucose tolerance and decreased placental leptin gene expression induced by hypermethylation (Bouchard et al. 2010). Likewise, epigenetic effects secondary to maternal dietary intake are a mechanistic source for variation in fetal and postnatal adiposity and growth (Lee et al. 2014).

\subsection{Structural Changes in Organs}

The separate and overlapping periods of organ development provide windows of susceptibility with long-term consequences for life course health. Gestational protein restriction may differentially influence not only development of the kidney, as noted previously, but also the pancreas. Associated with a predisposition to type 2 diabetes, gestational protein restriction may underlie decreased $\beta$-cell proliferation, increased $\beta$-cell apoptosis, and thereby smaller functional islets in the pancreas (Petrik et al. 1999). Similarly, lifelong cardiac health has prenatal origins with several intrauterine factors leading to postnatal endothelial dysfunction that increase heart disease and stroke risk (Thornburg 2004). In comparison to rats fed a normal protein diet, those with lowprotein exposure during gestation exhibited LBW and low heart weight, as well as significantly reduced numbers of cardiomyocytes (Corstius et al. 2005). The heart may be most sensitive to stressors in late gestation when cardiomyocytes become binucleated and permanently leave the cell cycle. A similar outcome is observed in relation to reduced placental gas exchange and hypoxemia, where the combination of increased cortisol and decreased IGF-1 also reduces cardiomyocyte binucleation (Thornburg et al. 2011). When combined later in life with hypertension, the reduction in cardiomyocytes may explain increased risks of heart failure. Organ structural integrity established early in development likely puts individuals at risk for adult disease susceptibility with age (e.g., Rinaudo and Wang 2012).

\section{Data and Methodological Challenges: Growth as a Predictor of Life Course Health Development}

Progress in understanding causality underlying the empirical associations between growth and life course health development depends on clarifying mechanistic links embedded in the growth process. A fundamental challenge is the wide range of data that are glossed to represent "growth" in these studies. First, a number of 
studies rely on assessments of size, not growth itself. Second, studies in this area rely on many different assessments of size, which do not assess the same biological processes. Third, many studies rely on proxies for growth or growth rate, such as patterns that emerge from size as plotted on growth charts.

\subsection{The Fallacy of Size as Growth}

While size is a cumulative outcome of previous growth, size alone does not reveal the path taken by an individual to achieve a particular size, and it is the path itself that embodies predictive forerunners (Eriksson et al. 2006). Growth is change in size over time within an individual; this is not captured by summary statistics of sample data. Hence, study design is critical: causality between growth and health outcomes requires within-individual repeated measures studies. These are more challenging to undertake in terms of sampling, subject compliance, and funding needs and demand unique analytic approaches (Lampl 2012b).

\subsection{Measurement Considerations}

Body size measurements are not interchangeable. A commonly measured parameter is weight, a relatively simple assessment to take. Weight is a nonspecific summary of mass, however, and does not differentiate lean mass and fat mass. Changes in weight are not a sensitive marker of growth in the developmental sense but can simply reflect the accumulation of tissue as energy intake exceeds utilization. A lack of appreciation for the not subtle differences between weight and length, or fat and lean mass, in their predictive power for later health outcomes is common. Taken together with different assessment periods, these differences may underlie discrepancies between studies (Baird et al. 2005; Monteiro and Victora 2005).

More specific issues for size assessment include the methodological need for attention to sources of error, including the precision (Cameron 2012) and reliability of measurement (Lampl et al. 2001) of the human body. This is essential when the object of study is growth, or the significant difference between sequential measurements unencumbered by measurement unreliability. Precision scales and specially constructed length/ height tools, including recumbent measuring boards for infants, are gold standard research tools required for longitudinal studies of individuals. By contrast, clinical and community-based screening measurements are less rigorous in their approaches for efficiency. Not infrequently, a lack of standardization between facilities reflects an absence of evidence-based clinical practice guidelines (Foote et al. 2011) with no small margins of error. A specific example includes methods for assessing adiposity, of particular importance in view of present health challenges. The primary technique for body fat estimation employs subcutaneous skinfold measures, while whole-body approaches, based on bioelectrical impedance analysis (BIA) and dual-energy X-ray absorptiometry (DXA), among others (Zemel 2012), are more common in research contexts. These methods are not, however, interchangeable, and variations in approach may explain reported inconsistencies in health outcomes based on size in early life. For example, fat mass as measured by DXA is highly correlated with BMI as a categorical variable (using $\geq 30 \mathrm{~kg} / \mathrm{m}^{2}$ as an indicator of obesity) (Flegal et al. 2009), while results comparing BMI and BIA outcomes show high specificity but not sensitivity (RomeroCorral et al. 2008).

Furthermore, phenomena such as secular changes in size make size-based assessments particularly problematic, with markers of the "normal" shifting through time as evidenced by demographic trends of increasing obesity. It is increasingly unclear whether one BMI criterion for obesity, for example, is appropriate globally (Deurenberg et al. 1998), further complicating interpretations of studies employing categorical outcomes.

\subsection{Proxies of Growth and Definitions of Normal Growth Trajectories}

A number of studies use patterns of "growth trajectories" that emerge when repeated measures data are plotted on growth curves over time as a 
study predictor or outcome. While a common diagnostic approach in the clinical setting, this is problematic. Growth charts are merely summary statistics of size for age and are not designed to represent growth paths followed by individuals (Lampl and Thompson 2007); any "pattern" only reflects how an individual's size compares to peers of similar age, who themselves are not staying the same relative to one another. The WHO child growth standards, widely implemented in clinical practice for identifying pathological growth (Grummer-Strawn et al. 2010), were developed from data collected by international sampling among "healthy" breastfed infants, with the goal of representing optimal growth trajectories (WHO MGRS 2006). These standards are not without criticism in achieving their prescriptive mission. Concerns include the validity of pathological interpretations applied to observed differences in weight gain trajectories between breastfed and non-breastfed infants (Griffiths et al. 2009), particularly in light of the actual rates of breastfeeding globally (Cai et al. 2012; Allen et al. 2013). It remains unclear what "optimal" growth patterns mean or if, indeed, such universals are appropriate goals.

Clinicians commonly diagnose pathological growth as a change in size for age of more than two major growth chart-based percentile lines between clinical assessments. While upward crossing of two or more major growth chart percentiles (often tagged "rapid growth") has been reported as increasing the odds of obesity in childhood and adolescence (Taveras et al. 2011; Ekelund et al. 2006), it is not always clear in studies whether "rapid growth" reflects exposure resulting from prior growth restriction, that is, "catch-up growth," or whether it is an outcome, as a shift in the tempo of growth prompted by another factor. "Percentile crossing" in weight-for-length is common during early development and may reflect more about normal variability in individual growth rates than pathology (Mei et al. 2004). Indeed, strategies for intervention that derive from proxies of growth rates may not serve individuals well. In general, the use of growth charts depends on the education of healthcare workers and their effectiveness when communicating with parents (Frongillo and Habicht 1997).

\section{Research Recommendations}

\subsection{Major Themes and Findings}

Three major themes emerge to guide future research efforts:

- Early growth trajectories are associated with life course health. The mechanistic understanding of these relationships is limited among humans; further research is required to discern micropathways that translate macropathways.

- Growth measurements need to be linked to their local context. As growth is an emergent process, the notion of optimal growth deserves reconsideration. Optimality of the system is a property reflecting flexibility under a variety of challenges, not a particular size or pattern of change under theoretical conditions.

- Prenatal healthcare services and the health of young girls and women must be a global public health priority (Barker et al. 2013). The true benefits of interventions in these realms may only be evident when measured at generational or intergenerational timescales, which may require new methods for evaluation and funding.

\subsection{Key Research Priorities}

\subsubsection{Basic/Mechanism Research}

- Refine our understanding of tissue differentiation timing and influences to delineate the specific effects of exposures during development and their influence on life course health.

- Integrate new technologies to assist in identifying how exogenous exposures affect endogenous processes in the short and long term [e.g., metabolomics (Jones et al. 2012), exposomics (Miller 2014)].

- Clarify how sex differences shape growth and body composition trajectories.

\subsubsection{Clinical Research}

- Explore alternate models of health promotion across female development, in particular 
methods that foster healthy nutrition and change family conditions, such as moving them out of adverse and impoverished environments.

- Incorporate new and creative technologies to document lifestyle effects on growth, in particular fostering the widespread availability of devices that can transmit data in real time via Internet-based telecommunication.

\subsubsection{Population/Epidemiologic Research}

- Prioritize funding to continue well-developed studies that already have long-term observations. This is of particular importance given the need to understand how intervention benefits unfold at generational and intergenerational timescales.

- Apply complex statistical modeling techniques to existing epidemiological data to examine individual variability in outcomes. Biological variation is a signature characteristic of mankind that must be embraced, rather than ignored, if we are to find meaningful ways to improve life course health.

\subsubsection{Translational Research}

- Ensure that appropriate animal models are utilized (e.g., Kilborn et al. 2002) and that experimental protocols are transparent to improve replication and accelerate their movement from bench to bedside.

- Share research findings with the communities in which observations are made, and develop educational materials that can benefit society at large. This will promote both the importance of science as a whole and mobilization of ingenuity and resourcefulness at local and national levels.

\subsection{Data and Method Development Priorities}

- Refine study design and methods to enhance collaborations between basic scientists, clinicians, and social scientists to deliver coherent, evidence-based research plans.

\subsubsection{Translational Priorities}

- Continue policy efforts aimed at ameliorating poor growth with attention to desired outcomes; increased weight attainment has different ends by comparison with length promotion (Adair et al. 2013). Given the current global obesity crisis and our already robust understanding of how excess weight and fat mass impact intergenerational well-being, such an effort can offer significant gains for current and future public health wellness.

- Improve public health messaging regarding what growth standards represent to help individual families implement health-promoting activities. Such an effort could include both family- and practitioner-based education programs to understand growth charts, as well as more robust efforts surrounding nutrition and exercise recommendations.

\subsubsection{Barriers to an Understanding of Growth and Life Course Health Development}

- Declining research budgets necessitate interdisciplinary projects that maximize yield. By encouraging collaboration to meet common goals, we can prioritize research programs that target several domains encompassed by the life course health development framework, ranging from the basic mechanistic level to how well-being crosses generational and intergenerational timespans.

- Increased participation is needed among family-focused studies, as it is clear that maternal and paternal factors influence health, as do the environments in which children are raised. Incentivizing participation by emphasizing health benefits will enable researchers to capture data at an intergenerational scale.

- Today's ecosystem is novel when conceptualized across evolutionary timescales, and our manmade environment poses new biological challenges. The major structural issues that affect health - poverty, deprivation, and inequality - require state- and nation-level attention, and the improvements in these areas can only be observed if we pay attention to outcomes over larger timespans. 


\section{References}

Aagaard, K., Ma, J., Antony, K. M., Ganu, R., Petrosino, J., \& Versalovic, J. (2014). The placenta harbors a unique microbiome. Science Translational Medicine, 6(237), 237ra65

Adair, L. S., \& Guilkey, D. K. (1997). Age-specific determinants of stunting in Filipino children. Journal of Nutrition, 127(27), 314-320.

Adair, L. S., Popkin, B. M., Akin, J. S., Guilkey, D. K., Guliano, S., Borja, J., et al. (2011). Cohort profile: The Cebu longitudinal health and nutrition survey. International Journal of Epidemiology, 40(3), 619-625.

Adair, L. S., Fall, C. H., Osmond, C., Stein, A. D., Martorell, R., Ramirez-Zea, M., et al. (2013). Associations of linear growth and relative weight gain during early life with adult health and human capital in countries of low and middle income: Findings from five birth cohort studies. The Lancet, 362(9891), 525-534.

Aghajafari, F., Nagulesapillai, T., Ronksley, P. E., Tough, S. C., O’Beirne, M., \& Rabi, D. M. (2013). Association between maternal serum 25-hydroxyvitamin D level and pregnancy and neonatal outcomes: Systematic review and meta-analysis of observational studies. British Medical Journal, 346, f1169.

Allen, J. A., Li, R., Scanlon, K. S., Perrine, C. G., \& Chen, J. (2013). Progress in increasing breastfeeding and reducing racial/ethnic differences - United States, 2000-2008 births. Morbidity and Mortality Weekly Report, 62(5), 77-80.

Arends, N., Johnston, L., Hokken-Koelega, A., van Duijn, C., de Ridder, M., Savage, M., et al. (2002). Polymorphism in the IGF-1 gene: Clinical relevance for short children born small for gestational age. Journal of Clinical Endocrinology and Metabolism, 87(6), 2720-2724.

Baird, J., Fisher, D., Lucas, P., Kleignen, J., Roberts, H., \& Law, C. (2005). Being big or growing fast: Systematic review of size and growth in infancy and later obesity. British Medical Journal, 331(7522), 929.

Barker, D. J. P. (2012). Sir Richard Doll Lecture: Developmental origins of chronic disease. Public Health, 126(3), 185-189.

Barker, D. J. P., \& Thornburg, K. (2013). The obstetric origins of health for a lifetime. Clinical Obstetrics and Gynecology, 56(3), 511-519.

Barker, D. J. P., Eriksson, J. G., Forsen, T., \& Osmond, C. (2005). Infant growth and income 50 years later. Archives of Disease in Childhood, 90, 272-273.

Barker, D. J. P., Bagby, S. P., \& Hanson, M. A. (2006). Mechanisms of disease: In utero programming in the pathogenesis of hypertension. Nature Clinical Practice Nephrology, 2(12), 700-707.

Barker, D. J. P., Kajantie, E., Osmond, C., Thornburg, K., \& Ericksson, J. G. (2011). How boys grow determines how long they live. American Journal of Human Biology, 23(3), 412-416.

Barker, D. J. P., Barker, M., Fleming, T., \& Lampl, M. (2013). Developmental biology: Support mothers to secure future public health. Nature, 504(7479), 209-211.

Bart van der Worp, H., Howells, D. W., Sena, E. S., Porritt, M. J., Rewell, S., O’Collins, V., et al. (2010). Can animal models of disease reliably inform human studies? PLoS Medicine, 7(3), e1000245.

Ben-Shlomo, Y., \& Kuh, D. (2002). A life course approach to chronic disease epidemiology: Conceptual models, empirical challenges and interdisciplinary perspectives. International Journal of Epidemiology, 31(2), 285-293.

Berry, W. D. J., Moriarty, C. M., \& Lau, Y.-S. (2002). Lead attenuation of episodic growth hormone secretion in male rats. International Journal of Toxicology, 21(2), 93-98.

Beydoun, H., \& Saftlas, A. F. (2008). Physical and mental health outcomes of prenatal maternal stress in human and animal studies: A review of recent evidence. Paediatric and Perinatal Epidemiology, 22(5), 438-466.

Bhutta, Z. A., Ghishan, F., Lindley, K., Memon, I. A., Mittal, S., \& Rhoads, J. M. (2004). Persistent and chronic diarrhea and malabsorption. Journal of Pediatric Gastroenterology and Nutrition, 39(Suppl 2), S711-S716.

Blumenshine, P., Egerter, S., Barclay, C. J., Cubbin, C., \& Braveman, P. A. (2010). Socioeconomic disparities in adverse birth outcomes: A systematic review. American Journal of Preventive Medicine, 39(3), 263-272.

Bobat, R., Coovadia, H., Moodley, D., Coutsoudis, A., \& Gouws, E. (2011). Growth in early childhood in a cohort of children born to HIV-1-infected women from Durban, South Africa. Annals of Tropical Paediatrics, 21(3), 203-210.

Bol, V. V., Reusens, B. M., \& Remacle, C. A. (2008). Postnatal catch-up growth after fetal protein restriction programs proliferation of rat preadipocytes. Obesity, 16(12), 2760-2763.

Bol, V., Delattre, A., Reusens, B., Raes, M., \& Remacle, C. (2009). Forced catch-up growth after fetal protein restriction alters the adipose tissue gene expression program leading to obesity in adult mice. American Journal of Physiology. Regulatory, Integrative and Comparative Physiology, 297, R291-R299.

Bouchard, L., Thibault, S., Guay, S.-P., Santure, M., Monpetit, A., St. Pierre, J., et al. (2010). Leptin gene epigenetic adaptation to impaired glucose metabolism during pregnancy. Diabetes Care, 33(11), 2436-2441.

Boyd, A., Golding, J., Macleod, J., Lawlor, D. A., Fraser, A., Henderson, J., et al. (2013). Cohort profile: The 'Children of the 90s' - the index offspring of the Avon Longitudinal Study of Parents and Children. International Journal of Epidemiology, 42(1), 111-127.

Brunner, S., Schmid, D., Zang, K., Much, D., Knoeferi, B., Kratzsch, J., et al. (2015). Breast milk leptin and adiponectin in relation to infant body composition up to 2 years. Pediatric Obesity, 10(1), 67-73.

Cai, X., Wardlaw, T., \& Brown, D. W. (2012). Global trends in exclusive breastfeeding. International Breastfeeding Journal, 7(1), 12. 
Cameron, N. (2003). Physical growth in a transitional economy: The aftermath of South African apartheid. Economics and Human Biology, 1(1), 29-42.

Cameron, N. (2007). Growth patterns in adverse environments. American Journal of Human Biology, 19(5), 615-621.

Cameron, N. (2012). The measurement of human growth. In N. Cameron \& B. Bogin (Eds.), Human growth and development (2nd ed., pp. 487-513). New York: Academic Press.

Cameron, N., \& Demerath, E. W. (2002). Critical periods in human growth and their relationship to diseases of aging. Yearbook of Physical Anthropology, 45, 159-184.

Checkley, W., Buckley, G., Gilman, R. H., Assis, A. M. O., Guerrant, R. L., Morris, S. S., et al. (2008). Multicountry analysis of the effects of diarrhoea on childhood stunting. International Journal of Epidemiology, 37(4), 816-830.

Clarkin, P. F. (2012). War, forced displacement and growth in Laotian adults. Annals of Human Biology, 39(1), 36-45.

Cole, T. J. (2003). The secular trend in human physical growth: A biological view. Economics and Human Biology, 1(2), 161-168.

Cook, J. T., \& Frank, D. A. (2008). Food security, poverty, and human development in the United States. Annals of the New York Academy of Sciences, 1136, 193-209.

Cooper, C., Westlake, S., Harvey, N., Javaid, K., Dennison, E., \& Hanson, M. (2006). Review: Developmental origins of osteoporotic fracture. Osteoporosis International, 17(3), 337-347.

Cooper, M. S. (2004). Sensitivity of bone to glucocorticoids. Clinical Science, 107(2), 111-123.

Corstius, H. B., Zimanyi, M. A., Maka, N., Herath, T., Thomas, W., van der Laarse, A., et al. (2005). Effect of intrauterine growth restriction on the number of cardiomyocytes in rat hearts. Pediatric Research, 57(6), 796-800.

Crooks, D. L. (1999). Child growth and nutritional status in a high-poverty community in eastern Kentucky. American Journal of Physical Anthropology, 109(1), 129-142.

Dabelea, D., Hanson, R. L., Lindsay, R. S., Pettitt, D. J., Imperatore, G., Gabir, M. M., et al. (2000). Intrauterine exposure to diabetes conveys risks for type 2 diabetes and obesity: A study of discordant sibships. Diabetes, 49(12), 2208-2211.

Dang, S., Yan, H., \& Yamamoto, S. (2008). High altitude and early childhood growth retardation: New evidence from Tibet. European Journal of Clinical Nutrition, 62(3), 342-348.

David, L. A., Maurice, C. F., Carmody, R. N., Gootenberg, D. B., Button, J. E., Wolfe, B. E., et al. (2014). Diet rapidly and reproducibly alters the human gut microbiome. Nature, 505(7484), 559-563.

Delgado, H., Valverde, V., Martorell, R., \& Klein, R. (1982). Relationship of maternal and infant nutrition to infant growth. Early Human Development, 6(3), 273-286.
DeLuca, H. F. (2004). Overview of general physiologic features and functions of vitamin D. American Journal of Clinical Nutrition, 80(6), 1689S-1696S.

Denham, M., Schell, L. M., Deane, G., Gallo, M. V., Ravenscroft, J., \& DeCaprio, A. P. (2005). Relationship of lead, mercury, mirex, dichlorodiphenyldichloroethylene, hexachlorobenzene, and polychlorinated biphenyls to timing of menarche among Akwesanse Mohawk girls. Pediatrics, 115(2), e127-e134.

Deurenberg, P., Yap, M., \& van Staveren, W. (1998). Body mass index and percent body fat: A meta-analysis among different ethnic groups. International Journal of Obesity and Related Metabolic Disorders, 22(12), 1164-1171.

Dewey, K. G., \& Mayers, D. R. (2011). Early child growth: How do nutrition and infection interact? Maternal \& Child Nutrition, 7(S3), 129-142.

Dobrova-Krol, N. A., van IJzendoorn, M. H., BakersmansKranenburg, M. J., Cyr, C., \& Juffer, F. (2008). Physical growth delays and stress dysregulation in stunted and nonstunted Ukrainian institution-reared children. Infant Behavior \& Development, 31(3), 539-553.

Dolinoy, D. C. (2008). The agouti mouse model: An epigenetic biosensor for nutritional and environmental alterations on the fetal epigenome. Nutrition Reviews, 66(Suppl 1), S7-S11.

Dolinoy, D. C., Weidman, J. R., Waterland, R. A., \& Jirtle, R. L. (2006). Maternal genistein alters coat color and protects Avy mouse offspring from obesity by modifying the fetal epigenome. Environmental Health Perspectives, 114(4), 567-572.

Dos Santos, C., Essioux, L., Teinturier, C., Tauber, M., Goffin, V., \& Bougneres, P. (2004). A common polymorphism of the growth hormone receptor is associated with increased responsiveness to growth hormone. Nature Genetics, 36(7), 720-724.

Duijts, L., Reiss, I. K., Brusselle, G., \& de Jongste, J. C. (2014). Early origins of chronic obstructive lung diseases across the life course. European Journal of Epidemiology, 29(12), 871-885.

Dyer, J. M., Hunter, R., \& Murphy, P. A. (2011). Relationship of social network size to infant birth weight in Hispanic and Non-Hispanic women. Journal of Immigrant and Minority Health, 13(3), 487-493.

Ekamper, P., van Poppel, F., Stein, A. D., Bijwaard, G. E., \& Lumey, L. H. (2015). Prenatal famine exposure and adult mortality from cancer, cardiovascular disease, and other causes through age 63 years. American Journal of Epidemiology. doi:10.1093/aje/kwu288.

Ekelund, U., Ong, K., Linne, Y., Neovius, M., Brage, S., Dunger, D. B., et al. (2006). Upward weight percentile crossing in infancy and early childhood independently predicts fat mass in young adults: The Stockholm Weight Development Study (SWEDES). American Journal of Clinical Nutrition, 83(2), 324-330.

Elford, J., Whincup, P., \& Shaper, A. G. (1991). Early life experience and adult cardiovascular disease: Longitudinal and case-control studies. International Journal of Epidemiololy, 20(4), 833-844.

Ellison, P. T., \& Jasienska, G. (2007). Constraint, pathology, and adaptation: How can we tell them 
apart? American Journal of Human Biology, 19(5), $622-630$.

Eriksson, J. G., Osmond, C., Kajantie, E., Forsen, T. J., \& Barker, D. J. P. (2006). Patterns of growth among children who later develop type 2 diabetes or its risk factors. Diabetologia, 49(12), 2853-2858.

Eveleth, P., \& Tanner, J. M. (1976). Worldwide variation in human growth (1st ed.). Cambridge: Cambridge University Press.

Eveleth, P., \& Tanner, J. M. (1990). Worldwide variation in human growth (2nd ed.). Cambridge: Cambridge University Press.

Fein, G. G., Jacobson, J. L., Jacobson, S. W., Schwartz, P. M., \& Dowler, J. K. (1984). Prenatal exposure to polychlorinated biphenyls: Effects on birth size and gestational age. Journal of Pediatrics, 105(2), 315-332.

Fields, D. A., \& Demerath, E. W. (2012). Relationship of insulin, glucose, leptin, IL-6 and TNF- $\alpha$ in human breast milk with infant growth and body composition. Pediatric Obesity, 7(4), 304-312.

Finucane, M. M., Stevens, G. A., Cowan, M. J., Danaei, G., Lin, J. K., Paciorek, C. J., et al. (2011). National, regional, and global trends in body-mass index since 1980: Systematic analysis of health examination surveys and epidemiological studies with 960 country-years and 9.1 million participants. The Lancet, 377(9765), 557-567.

Fiorito, L. M., Marini, M., Francis, L. A., SmiciklasWright, H., \& Birch, L. L. (2009). Beverage intake of girls at age 5 y predicts adiposity and weight status in childhood and adolescence. American Journal of Clinical Nutrition, 90(4), 935-942.

Flegal, K. M., Shepherd, J. A., Looker, A. C., Graubard, B. I., Borrud, L. G., Ogden, C. L., et al. (2009). Comparisons of percentage body fat, body mass index, waist circumference, and waist-stature ratio in adults. American Journal of Clinical Nutrition, 89(2), 500-508.

Foote, J. M., Brady, L. H., Burke, A. L., Cook, J. S., Dutcher, M. E., Gradoville, K. M., et al. (2011). Development of an evidence-based clinical practice guideline on linear growth measurement of children. Journal of Pediatric Nursing, 26(4), 312-324.

Forsdahl, A. (1977). Are poor living conditions in childhood and adolescence an important risk factor for arteriosclerotic heart disease? British Journal of Preventive \& Social Medicine, 31(2), 91-95.

Fowden, A. L., Giussani, D. A., \& Forhead, A. J. (2006). Intrauterine programming of physiological systems: Causes and consequences. Physiology, 21(1), 29-37.

Frankenberg, E., Suriastini, W., \& Thomas, D. (2005). Can expanding access to basic healthcare improve children's health status? Lessons from Indonesia's 'midwife in the village' programme. Population Studies, 59(1), 5-19.

Frongillo, E. A., \& Habicht, J. P. (1997). Investigating the weanling's dilemma: Lessons from Honduras. Nutrition Reviews, 55(11), 390-395.
Frongillo, E. A., de Onis, M., \& Hanson, K. M. P. (1997). Socioeconomic and demographic factors are associated with worldwide patterns of stunting and wasting of children. Journal of Nutrition, 127(12), 2302-2309.

Funkhouser, L. J., \& Bordenstein, S. R. (2013). Mom knows best: The universality of maternal microbial transmission. PLoS Biology, 11(8), e1001631.

Gasser, B., Mauss, Y., Ghnassia, J. P., Favre, R., Kohler, M., Yu, O., et al. (1993). A quantitative study of normal nephrogenesis in the human fetus: Its implication in the natural history of kidney changes due to low obstructive uropathies. Fetal Diagnosis and Therapy, $8(6), 371-384$.

Gennser, G., Rymark, P., \& Isbert, P. (1988). Low birth weight and risk of high blood pressure in adulthood. British Medical Journal, 296, 1498-1500.

Gidrewizc, D. A., \& Fenton, T. R. (2014). A systematic review and meta-analysis of the nutrient content of preterm and term breast milk. BMC Pediatrics, 14, 216.

Gluckman, P. D., \& Hanson, M. A. (2006). Mismatch: The lifestyle diseases timebomb. Oxford: Oxford University Press.

Gluckman, P. D., Hanson, M. A., \& Spencer, H. G. (2005). Predictive adaptive responses and human evolution. TRENDS in Ecology and Evolution, 20(10), 527-533.

Gluckman, P. D., Hanson, M. A., Cooper, C., \& Thornburg, K. (2008). Effect of in utero and early-life conditions on adult health and disease. New England Journal of Medicine, 359(1), 61-73.

Godfrey, K., Robinson, S., Barker, D. J., Osmond, C., \& Cox, V. (1996). Maternal nutrition in early and late pregnancy in relation to placental and fetal growth. British Medical Journal, 312(7028), 410-414.

Gresham, E., Byles, J. E., Bisquera, A., \& Hure, A. J. (2014). Effects of dietary interventions on neonatal and infant outcomes: A systematic review and metaanalysis. American Journal of Clinical Nutrition, 100(5), 1298-1321.

Griffiths, P. L., Rousham, E. K., Norris, S. A., Pettifor, J. M., \& Cameron, N. (2008). Socio-economic status and body composition outcomes in urban South African children. Archives of Disease in Childhood, 93(10), 862-867.

Griffiths, L. J., Smeeth, L., Sherburne Hawkins, S., Cole, T. J., \& Dezateux, C. (2009). Effects of infant feeding practice on weight gain from birth to 3 years. Archives of Disease in Childhood, 94(8), 577-582.

Grummer-Strawn, L. M., Reinold, C., \& Krebs, N. F. (2010). Use of World Health Organization and CDC growth charts for children aged 0-59 months in the United States. Morbidity and Mortality Weekly Report, 59(RR09), 1-15.

Guarner, F., \& Malagelada, J. R. (2003). Gut flora in health and disease. The Lancet, 361(9356), 512-519.

Gude, N. M., Roberts, C. T., Kalionis, B., \& King, R. G. (2004). Growth and function of the normal human placenta. Thrombosis Research, 114(5-6), 397-407.

Guo, Y. L., Lin, C. J., Yao, W. J., Ryan, J. J., \& Hsu, C. C. (1994). Musculoskeletal changes in children prenatally exposed to polychlorinated biphenyls and related com- 
pounds (Yu-Cheng children). Journal of Toxicology and Environmental Health, 41(1), 83-93.

Hack, M. (2006). Young adult outcomes of very-lowbirth-weight children. Seminars in Fetal and Neonatal Medicine, 11(2), 127-137.

Hales, C. N., \& Barker, D. J. (2001). The thrifty phenotype hypothesis. British Medical Bulletin, 60, 5-20.

Halfon, N., \& Forrest, C. B. (2017). The emerging theoretical framework of life course health development. In N. Halfon, C. B. Forrest, R. M. Lerner, \& E. Faustman (Eds.), Handbook of life course health-development science. Cham: Springer.

Halfon, N., \& Hochstein, M. (2002). Life course health development: An integrated framework for developing health, policy, and research. Milbank Quarterly, 80(3), 433-479.

Hall, B. K. (2005). Bones and cartilage: Developmental and evolutionary skeletal biology. New York: Elsevier Academic Press.

Hammond, P. B., Chernausek, S. D., Succop, P. A., Shukla, R., \& Bornschein, R. L. (1989). Mechanisms by which lead depresses linear and ponderal growth in weanling rats. Toxicology and Applied Pharmacology, 99(3), 474-486.

Hanson, M. A., \& Gluckman, P. D. (2014). Early developmental conditioning of later health and disease: Physiology or pathophysiology? Physiology Reviews, 94, 1027-1094.

Harper, K., \& Armelagos, G. J. (2010). The changing disease-scape in the third epidemiological transition. International Journal of Environmental Research and Public Health, 7(2), 675-697.

Hertzman, C. (2012). Putting the concept of biological embedding in historical perspective. Proceedings of the National Academy of Sciences, 109(Suppl 2), 17160-17167.

Hinchliffe, S. A., Sargent, P. H., Howard, C. V., Chan, Y. F., \& van Velzen, D. (1991). Human intrauterine renal growth expressed in absolute number of glomeruli assessed by the dissector method and Cavalieri principle. Laboratory Investigation, 64(6), 777-784.

Holland, J. H. (1992). Complex adaptive systems. Daedalus, 121(1), 17-30.

Howe, L. D., Tilling, K., Galobardes, B., Davey Smith, G., Gunnell, D., \& Lawlor, D. A. (2012). Socioeconomic differences in childhood growth trajectories: At what age do height inequalities emerge? Journal of Epidemiology and Community Health, 66(2), 143-148.

Ibrahim, M. M. (2010). Subcutaneous and visceral adipose tissue: Structural and functional differences. Obesity Reviews, 11(1), 11-18.

Isaksson, O. G. P., Jansson, J.-O., \& Gause, I. A. M. (1982). Growth hormone stimulates longitudinal bone growth directly. Science, 216(4551), 1237-1239.

Jablonski, N. G., \& Chaplin, G. (2000). The evolution of human skin coloration. Journal of Human Evolution, 39(1), 57-106.

Jansson, N., Pettersson, J., Haafiz, A., Ericsson, A., Palmberg, I., Tranberg, M., et al. (2006). Downregulation of placental transport of amino acids precedes the development of intrauterine growth restriction in rats fed a low protein diet. Journal of Physiology, 576(Pt 3), 935-946.

Jansson, N., Nilsfelt, A., Gellerstedt, M., Wennergren, M., Rossander-Hulthen, L., Powell, T. L., et al. (2008). Maternal hormones linking maternal body mass index and dietary intake to birth weight. American Journal of Clinical Nutrition, 87(6), 1743-1749.

Johnson, L., Mander, A. P., Jones, L. R., Emmett, P. M., \& Jebb, S. A. (2009). Energy-dense, low-fiber, highfat dietary pattern is associated with increased fatness in childhood. American Journal of Clinical Nutrition, 87(4), 846-854.

Johnston, F. E. (1998). The ecology of postnatal growth. In S. J. Ulijaszek, F. E. Johnston, \& M. A. Preece (Eds.), Cambridge Encyclopedia of human growth and development (pp. 315-319). Cambridge: Cambridge University Press.

Jones, R. L., Cederberg, H. M., Wheeler, S. J., Poston, L., Hutchison, C. J., Seed, P. T., et al. (2010). Relationship between maternal growth, infant birthweight and nutrient partitioning in teenage pregnancies. British Journal of Obstetrics \& Gynecology, 117, 200-211.

Jones, D. P., Park, Y., \& Ziegler, T. R. (2012). Nutritional metabolomics: Progress in addressing complexity in diet and health. Annual Review of Nutrition, 32, 183-202.

Juez, G., Diaz, S., Casado, M., Duran, E., Salvatierra, A., Peralta, O., et al. (1983). Growth pattern of selected urban Chilean infants during exclusive breast-feeding. American Journal of Clinical Nutrition, 38(3), 462-468.

Kajantie, E., Dunkel, L., Turpeinen, U., Stenman, U.-H., Wood, P. J., Nuutila, M., et al. (2003). Placental $11 \beta$-hydroxysteroid dehydrogenase- 2 and fetal cortisol/cortisone shuttle in small preterm infants. Journal of Clinical Endocrinology and Metabolism, 88(1), 493-500.

Karsenty, G., \& Yadav, V. (2011). Regulation of bone mass by serotonin: Molecular biology and therapeutic implications. Annual Review of Medicine, 62, 323-331.

Kelishadi, R., \& Poursafa, P. (2014). A review on the genetic, environmental, and lifestyle aspects of the early-life origin of cardiovascular disease. Current Problems in Pediatric and Adolescent Health Care, 44(3), 54-72.

Kelishadi, R., Ardalan, G., Gheiratmand, R., Gouya, M. M., Razahi, E. M., Delavari, A., et al. (2007). Association of physical activity and dietary behaviours in relation to the body mass index in a national sample of Iranian children and adolescents: CASPIAN Study. Bulletin of the World Health Organization, 85(1), 19-26.

Kermack, W. O., McKendrick, A. G., \& McKinlay, P. L. (1934). Death-rates in Great Britain and Sweden. Some general regularities and their significance. The Lancet, 223(5770), 698-703.

Keyes, L. E., Armaza, J. F., Niermeyer, S., Vargas, E., Young, D. A., \& Moore, L. G. (2003). Intrauterine growth restriction, preeclampsia, and intrauterine mortality at high altitude in Bolivia. Pediatric Research, 54(1), 20-25. 
Kilborn, S. H., Trudel, G., \& Uhthoff, H. (2002). Review of growth plate closure compared with age at sexual maturity and lifespan in laboratory animals. Contemporary Topics in Laboratory Animal Science, 41(5), 21-26.

Koenig, J. E., Spor, A., Scalfone, N., Fricker, A. D., Stombaugh, J., Knight, R., et al. (2011). Succession of microbial consortia in the developing infant gut microbiome. Proceedings of the National Academy of Sciences, 108(Suppl 1), 4578-4585.

Krieger, N. S., \& Smith, G. (2004). "Bodies count," and body counts: Social epidemiology and embodying inequality. Epidemiology Reviews, 26, 92-103.

Kuczmarski, R. J., Ogden, C. L., Grummer-Strawn, L. M., Flegal, K. M., Guo, S. S., Wei, R., et al. (2000). CDC growth charts: United States (Vol. Vol. 314). Hyattsville: National Center for Health Statistics.

Kurokawa, K., Itoh, T., Kuwahara, T., Oshima, K., Toh, H., Toyoda, A., et al. (2007). Comparative metagenomics revealed commonly enriched gene sets in human gut microbiomes. DNA Research, 14(4), 169-181.

Lakshman, R., Zhang, J., Zhang, J., Koch, F. S., Marcus, C., Ludvigsson, J., et al. (2013). Higher maternal education is associated with favourable growth of young children in different countries. Journal of Epidemiology and Community Health, 67(7), 595-602.

Lampl, M. (2009). Human growth from the cell to the organism: Saltations and integrative physiology. Annals of Human Biology, 36(5), 478-495.

Lampl, M. (2012a). Limitation of growth chart curves in terms of individual growth biology. In V. R. Preedy (Ed.), Handbook of growth and growth monitoring in health and disease (pp. 3013-3029). New York: Springer.

Lampl, M. (2012b). Perspectives on modelling human growth: Mathematical models and growth biology. Annals of Human Biology, 39(5), 342-351.

Lampl, M., \& Johnson, M. L. (1998). Normal human growth as saltatory: Adaptation through irregularity. In K. Newell \& P. Molenaar (Eds.), Dynamical systems in development (pp. 15-38). Hillsdale: Lawrence Erlbaum, Inc..

Lampl, M., \& Thompson, A. L. (2007). Growth chart curves do not describe individual growth biology. American Journal of Human Biology, 19(5), 643-653.

Lampl, M., Veldhuis, J. D., \& Johnson, M. L. (1992). Saltation and stasis: A model of human growth. Science, 258(5083), 801-803.

Lampl, M., Birch, L., Picciano, M. F., Johnson, M. L., \& Frongillo, E. A., Jr. (2001). Child factor in measurement dependability. American Journal of Human Biology, 13(4), 548-557.

Lavy, V., Strauss, J., Thomas, D., \& de Vreyer, P. (1996). Quality of health care, survival, and health outcomes in Ghana. Journal of Health Economics, 15(3), 333-357.

Lee, H.-S., Barraza-Villarreal, A., Biessy, C., DuarteSalles, T., Sly, P. D., Ramakrishnan, U., et al. (2014). Dietary supplementation with polyunsaturated fatty acid during pregnancy modulates
DNA methylation at IGF2/H19 imprinted genes and growth of infants. Physiological Genomics, 46(23), 851-857.

Ley, R. E., Backhed, F., Turnbaugh, P., Lozupone, C. A., Knight, R. D., \& Gordon, J. I. (2005). Obesity alters gut microbial ecology. Proceedings of the National Academy of Sciences, 102(31), 11070-11075.

Li, R., Fein, S. B., \& Grummer-Strawn, L. M. (2010). Do infants fed from bottles lack self-regulation of milk intake compared with directly breastfed infants? Pediatrics, 125(6), e1386-e1393.

Lindo, J. M. (2011). Parental job loss and infant health. Journal of Health Economics, 30(5), 869-879.

Lorenz, K. (1935). The companion in the bird's world: The fellow-member of the species as releasing factor of social behavior. Journal fur Ornithologie Beiblatt (Leipzig), 83, 137-213.

Lumey, L. H., \& Stein, A. D. (1997). In utero exposure to famine and subsequent fertility: The Dutch Famine Birth Cohort Study. American Journal of Public Health, 87(12), 1962-1966.

Lutfiyya, M. N., Lipsky, M. S., Wisdom-Behounek, J., \& Inpanbutr-Martinkus, M. (2007). Is rural residency a risk factor for overweight and obesity for U.S. children? Obesity, 15(9), 2348-2356.

Malina, R. M. (2004). Secular trends in growth, maturation and physical performance: A review. Anthropology Reviews, 67, 3-31.

Malina, R. M., Pena Reyes, M. E., Bali Chavez, G., \& Little, B. B. (2011). Secular change in height and weight of indigenous school children in Oaxaca, Mexico, between the 1970s and 2007. Annals of Human Biology, 38(6), 691-701.

Martorell, R., Yarbrough, C., Lechtig, A., Delgado, H., \& Klein, R. E. (1977). Genetic-environmental interactions in physical growth. Acta Padiatrica Scandinavia, 66(5), 579-584.

Martorell, R., Kettel Khan, L., \& Grummer-Strawn, L. M. (2000). Overweight and obesity in preschool children from developing countries. International Journal of Obesity and Related Metabolic Disorders, 24(8), 959-967.

Mastorakos, G., \& Ilias, I. (2003). Maternal and fetal hypothalamic-pituitary-adrenal axes during pregnancy and postpartum. Annals of the New York Academy of Sciences, 997, 136-149.

McBride, W. G. (1961). Thalidomide and congenital abnormalities. The Lancet, 278(7216), 1358.

McDade, T., \& Worthman, C. M. (1998). The weanling's dilemma reconsidered: A biocultural analysis of breastfeeding ecology. Developmental and Behavioral Pediatrics, 19(4), 286-299.

McEwen, B. S., \& Wingfield, J. C. (2003). The concept of allostasis in biology and biomedicine. Hormones and Behavior, 43(1), 2-15.

McKeown, T., \& Record, R. (1954). Influence of pre-natal environment on correlation between birth weight and parental height. American Journal of Human Genetics, 6(4), 456-463.

Mei, Z., Grummer-Strawn, L. M., Thompson, D., \& Dietz, W. H. (2004). Shifts in percentiles of growth 
during early childhood: Analysis of longitudinal data from the California Child Health and Development Study. Pediatrics, 113(6), e617-e627.

Mericq, V., Medina, P., Kakarieka, E., Marquez, L., Johnson, M. C., \& Iniguez, G. (2009). Differences in expression and activity of $11 \beta$-hydroxysteroid dehydrogenase type 1 and 2 in human placentas of term pregnancies according to birth weight and gender. European Journal of Endocrinology, 161(3), 419-425.

Miller, G. W. (2014). The exposome: A primer. Waltham: Academic Press.

Mongomery, S. M., Bartley, M. J., \& Wilkinson, R. G. (1997). Family conflict and slow growth. Archives of Disease in Childhood, 77(4), 326-330.

Monteiro, P. O. A., \& Victora, C. G. (2005). Rapid growth in infancy and childhood and obesity in later life - A systematic review. Obesity Reviews, 6(2), 143-154.

Moore, V. M., Davies, M. J., Willson, K. J., Worsley, A., \& Robinson, J. S. (2004). Dietary composition of pregnancy women is related to size of the baby at birth. Journal of Nutrition, 134(7), 1820-1826.

Morrison, R. F., \& Farmer, S. R. (2000). Hormonal signaling and transcriptional control of adipocyte differentiation. Journal of Nutrition, 130(12), 3116S-3121S.

Neel, J. V. (1962). Diabetes Mellitus: A "thrifty" genotype rendered detrimental by "progress"? American Journal of Human Genetics, 14(4), 353-362.

Nesse, R. M. (2005). Maladaptation and natural selection. The Quarterly Review of Biology, 80(1), 62-70.

Neufeld, L. M., Haas, J. D., Grajeda, R., \& Martorell, R. (2004). Changes in maternal weight from the first to second trimester of pregnancy are associated with fetal growth and infant length at birth. American Journal of Clinical Nutrition, 79(4), 646-652.

Neumann, C., \& Harrison, G. (1994). Onset and evolution of stunting in infants and children. Examples from the Human Nutrition Collaborative Research Support Program. Kenya and Egypt studies. European Journal of Clinical Nutrition, 48(Suppl1), S90-S102.

Noonan, K. J., Farnum, C. E., Leiferman, E. M., Lampl, M., Markel, M. D., \& Wilsman, N. J. (2004). Growing pains: Are they due to increased growth during recumbency as documented in a lamb model? Journal of Pediatric Orthopedics, 24(6), 726-731.

Olds, T., Maher, C., Zumin, S., Peneau, S., Lioret, S., Castebon, K., et al. (2011). Evidence that the prevalence of childhood overweight is plateauing: Data from nine countries. International Journal of Pediatric Obesity, 6(5-6), 342-360.

Omran, A. R. (1971). The epidemiologic transition. A theory of the epidemiology of population change. The Milbank Memorial Fund Quarterly, 49(4), 509-538.

Ong, K. K., \& Dunger, D. B. (2002). Perinatal growth failure: The road to obesity, insulin resistance and cardiovascular disease in adults. Best Practice \& Research. Clinical Endocrinology \& Metabolism, 16(2), 191-207.

Oreffo, R. O., Lashbrooke, B., Roach, H. I., Clarke, N. M., \& Cooper, C. (2003). Maternal protein deficiency affects mesenchymal stem cell activity in the developing offspring. Bone, 33(1), 100-107.
Ounsted, M. (1965). Maternal constraint of foetal growth in man. Developmental Medicine and Child Neurology, 7(5), 479-491.

Owen, C. G., Martin, R. M., Whincup, P. H., Davey Smith, G., \& Cook, D. G. (2005). Effect of infant feeding on the risk of obesity across the life course: A quantitative review of published evidence. Pediatrics, 115(5), 1367-1377.

Ozanne, S. E., \& Constancia, M. (2007). Mechanisms of disease: The developmental origins of disease and the role of the epigenotype. Nature Clinical Practice Endocrinology \& Metabolism, 3(7), 539-546.

Paciorek, C. J., Stevens, G. A., Finucane, M. M., Ezzati, M., \& Nutrition Impact Model Study Group. (2013). Children's height and weight in rural and urban populations in low-income and middle-income countries: A systematic analysis of population-representative data. The Lancet Global Health, 1(5), e300-e309.

Painter, R. C., Roseboom, T. J., Bossuyt, P. M., Osmond, C., Barker, D. J. P., \& Bleker, O. P. (2005a). Adult mortality at age 57 after prenatal exposure to the Dutch famine. European Journal of Epidemiology, 20(8), 673-676.

Painter, R. C., Roseboom, T. J., van Montfrans, G. A., Bossuyt, P. M. M., Krediet, R. T., Osmond, C., et al. (2005b). Microalbuminuria in adults after prenatal exposure to the Dutch Famine. Journal of the American Society of Nephrology, 16(1), 189-194.

Painter, R. C., Osmond, C., Gluckman, P. D., Hanson, M. A., Phillips, D. I. W., \& Roseboom, T. J. (2008a). Transgenerational effects of prenatal exposure to the Dutch famine on neonatal adiposity and health in later life. BJOG, 115(10), 1243-1249.

Painter, R. C., Westendorp, R. G. J., de Rooij, S. R., Osmond, C., Barker, D. J. P., \& Roseboom, T. J. (2008b). Increased reproductive success of women after prenatal undernutrition. Human Reproduction, 23(11), 2591-2595.

Palmer, C., Bik, E. M., DiGiulio, D. B., Relman, D. A., \& Brown, P. O. (2007). Development of the human infat intestinal microbiota. PLoS Biology, 5, e177.

Paneth, N., \& Susser, M. (1995). Early origin of coronary heart disease (the "Barker hypothesis"). British Medical Journal, 310(6977), 411-412.

Pawson, I. G., \& Huicho, L. (2010). Persistence of growth stunting in a Peruvian high altitude community, 1964-1999. American Journal of Human Biology, 22(3), 367-374.

Peck, M. N., \& Lundberg, O. (1995). Short stature as an effect of economic and social conditions in childhood. Social Science \& Medicine, 41(5), 733-738.

Peter, I. S., \& Davidson, E. H. (2011). Evolution of gene regulatory networks controlling body plan development. Cell, 144(6), 970-985.

Petrik, J., Reusens, B., Arany, E., Remacle, C., Coelho, C., Hoet, J. J., et al. (1999). A low protein diet alters the balance of islet cell replication and apoptosis in the fetal and neonatal rat and is associated with a reduced pancreatic expression of insulin-like growth factor-II. Endocrinology, 140(10), 4861-4873. 
Popkin, B. M., Adair, L. S., \& Wen Ng, S. (2012). Global nutrition transition and the pandemic of obesity in developing countries. Nutrition Reviews, 70(1), 3-21.

Prentice, A. (2008). Vitamin D deficiency: A global perspective. Nutrition Reviews, 66(S2), S153-S164.

Rahman, A., Bunn, J., Lovel, H., \& Creed, F. (2007). Association between antenatal depression and low birthweight in a developing country. Acta Psychiatrica Scandinavica, 115(6), 481-486.

Ramakrishnan, U., Grant, F., Goldenberg, T., Zongrone, A., \& Martorell, R. (2012). Effect of women's nutrition before and during early pregnancy on maternal and infant outcomes: A systematic review. Paediatric and Perinatal Epidemiology, 26(Suppl 1), 285-301.

Ravelli, A. C., van der Meulen, J. H., Osmond, C., Barker, D. J. P., \& Bleker, O. P. (1999). Obesity at the age of $50 \mathrm{y}$ in men and women exposed to famine prenatally. American Journal of Clinical Nutrition, 70(5), 811-816.

Ravelli, A. C. J., van der Meulen, J. H. P., Michels, R. P. J., Osmond, C., Barker, D. J. P., Hales, C. N., et al. (1998). Glucose tolerance in adults after prenatal exposure to famine. The Lancet, 351(9097), 173-177.

Ravelli, G. P., Stein, Z. A., \& Susser, M. W. (1976). Obesity in young men after famine exposure in utero and early infancy. New England Journal of Medicine, 295(7), 349-353.

Regidor, E., Martinez, D., Santos, J. M., Calle, M. E., Ortega, P., \& Astasio, P. (2012). New findings do not support the neomaterialist theory of the relation between income inequality and infant mortality. Social Science \& Medicine, 75(4), 752-753.

Ricco, R., Nogueira-de-Almeida, C., Del Ciamp, L., Daneluzzi, J., Ferlin, M., \& Muccillo, G. (2001). Growth of exclusively breast-fed infants from a poor urban population. Archivos Latinoamericanos de Nutrición, 51, 122-126.

Richter, L., Norris, S., Pettifor, J., Yach, D., \& Cameron, N. (2007). Cohort profile: Mandela's children: The 1990 birth to twenty study in South Africa. International Journal of Epidemiology, 36(3), 504-511.

Rinaudo, P., \& Wang, E. (2012). Fetal programming and metabolic syndrome. Annual Review of Physiology, 74, 107-130.

Robker, R. L., Akison, L. K., Bennett, B. D., Thrupp, P. N., Chura, L. R., Russell, D. L., et al. (2009). Obese women exhibit differences in ovarian metabolites, hormones, and gene expression compared with moderate-weight women. The Journal of Clinical Endocrinology and Metabolism, 94(5), 1533-1540.

Romero-Corral, A., Somers, V. K., Sierra-Johnson, J., Thomas, R. J., Collazo-Clavell, M. L., Korinek, J., et al. (2008). Accuracy of body mass index in diagnosing obesity in the adult general population. International Journal of Obesity, 32(6), 959-966.

Rondo, P. H. C., Ferreira, R. F., Nogueira, F., Ribeiro, M. C. N., Lobert, H., \& Artes, R. (2003). Maternal psychological stress and distress as predictors of low birth weight, prematurity and intrauterine growth retardation. European Journal of Clinical Nutrition, 57(2), 266-272.
Roseboom, T. J., van der Meulen, J. H., Ravelli, A. C. J., van Montfrans, G. A., Osmond, C., Barker, D. J. P., et al. (1999). Blood pressure in adults after prenatal exposure to famine. Journal of Hypertension, 17(3), 325-330.

Roseboom, T. J., van der Meulen, J. H., Osmond, C., Barker, D. J. P., Ravelli, A. C., \& Bleker, O. P. (2000). Plasma lipid profiles in adults after prenatal exposure to the Dutch famine. American Journal of Clinical Nutrition, 72(5), 1101-1106.

Roseboom, T. J., van der Meulen, J. H., Osmond, C., Barker, D. J. P., Ravelli, A. C., \& Bleker, O. P. (2001). Adult survival after prenatal exposure to the Dutch famine 1944-45. Paediatric and Perinatal Epidemiology, 15(3), 220-225.

Roseboom, T. J., Painter, R. C., van Abeelen, A. F. M., Veenendaal, M. V. E., \& de Rooij, S. R. (2011). Hungry in the womb: What are the consequences? Lessons from the Dutch famine. Maturitas, 70(2), 141-145.

Salam, M. T., Millstein, J., Li, Y. F., Lurmann, F. W., Margolis, H. G., \& Filliland, F. D. (2005). Birth outcomes and prenatal exposure to ozone, carbon monoxide, and particulate matter: Results from the Children's Health Study. Environmental Health Perspectives, 113(11), 1638-1644.

Saleemi, M., Ashraf, R., Mellander, L., \& Zaman, S. (2001). Determinants of stunting at 6, 12, 24 and 60 months and postnatal linear growth in Pakistani children. Acta Paediatrica, 90(11), 1304-1308.

Sanguanklin, N., McFarlin, B. L., Park, C. G., Giurgescu, C., Finnegan, L., White-Traut, R., et al. (2014). Effects of the 2011 flood in Thailand on birth outcomes and perceived social support. Journal of Obstetric, Gynecologic, and Neonatal Nursing, 43(4), 435-444.

Savino, F., Liguori, S. A., Fissore, M. F., \& Oggero, R. (2009). Breast milk hormones and their protective effect on obesity. International Journal of Pediatric Endocrinology, 2009, e327505.

Schell, L. M., Gallo, M. V., Denham, M., \& Ravenscroft, J. (2006). Effects of pollution on human growth and development: An introduction. Journal of Physiological Anthropology, 25(1), 103-112.

Schell, L. M., Denham, M., Stark, A. D., Parsons, P. J., \& Schulte, E. E. (2009). Growth of infants' length, weight, head and arm circumferences in relation to low levels of blood lead measured serially. American Journal of Human Biology, 21(2), 180-187.

Schlotz, W., \& Phillips, D. I. W. (2009). Fetal origins of mental health: Evidence and mechanisms. Brain, Behavior, and Immunity, 23(7), 905-916.

Schmatz, M., Madan, J., Marino, T., \& Davis, J. (2010). Maternal Obesity: The interplay between inflammation, mother, and fetus. Journal of Perinatology, 30(7), 441-446.

Schuster, S., Hechler, C., Gebauer, C., Kiess, W., \& Kratzsch, J. (2011). Leptin in maternal serum and breast milk: Association with infants' body weight gain in a longitudinal study over 6 months of lactation. Pediatric Research, 70(6), 633-637.

Sederquist, B., Fernandez-Vojvodich, P., Zaman, F., \& Savendahl, L. (2014). Impact of inflammatory 
cytokines on longitudinal bone growth. Journal of Molecular Endocrinology, 53(1), T35-T44.

Shenkin, S. D., Starr, J. M., \& Deary, I. J. (2004). Birth weight and cognitive ability in childhood: A systematic review. Psychological Bulletin, 130(6), 989-1013.

Silventoinen, K., Rokholm, B., Kaprio, J., \& Sorensen, T. I. A. (2010). The genetic and environmental influences on childhood obesity: A systematic review of twin and adoption studies. International Journal of Obesity, 34(1), 29-40.

Simkhada, B., van Tejilingen, E. R., Porter, M., \& Simkhada, P. (2008). Factors affecting the utilization of antenatal care in developing countries: Systematic review of the literature. Journal of Advanced Nursing, 61(3), 244-260.

Souberbiellea, J.-C., Body, J.-J., Lappe, J. M., Plebani, M., Shoenfeld, Y., Wang, T. J., et al. (2010). Vitamin $\mathrm{D}$ and musculoskeletal health, cardiovascular disease, autoimmunity and cancer: Recommendations for clinical practice. Autoimmunity Reviews, 9(11), 709-715.

Sram, R. J., Binkova, B. B., Dejmek, J., \& Bobak, M. (2005). Ambient air pollution and pregnancy outcomes: A review of the literature. Environmental Health Perspectives, 113(4), 375-382.

Stein, A. D., Zybert, P. A., van der Pal-de Bruin, K. M., \& Lumey, L. H. (2006). Exposure to famine during gestation, size at birth, and blood pressure at age $59 \mathrm{y}$ : Evidence from the dutch famine. European Journal of Epidemiology, 21(10), 759-765.

Stinson, S. (2012). Growth variation: Biological and cultural factors. In S. Stinson, B. Bogin, \& D. O'Rourke (Eds.), Human biology: An evolutionary and biocultural perspective (2nd ed., pp. 587-636). New York: John Wiley \& Sons, Inc..

Stockard, C. R. (1921). Developmental rate and structural expression: An experimental study of twins, "double monsters" and single deformities, and the interaction among embryonic organs during their origin and development. The American Journal of Anatomy, 28(2), 115-277.

Strutz, K. L., Hogan, V. K., Siega-Riz, A. M., Suchindran, C. M., Halpern, C. T., \& Hussey, J. M. (2014). Preconception stress, birth weight, and birth weight disparities among US women. American Journal of Public Health, 104(8), e125-e132.

Subramanian, S. V., Ozaltin, E., \& Finlay, J. E. (2011). Height of nations: A socioeconomic analysis of cohort differences and patterns among women in 54 low- to middle-income countries. PLoS ONE, 6(4), e 18962.

Susser, M., \& Stein, Z. (1994). Timing in prenatal nutrition: A reprise of the Dutch Famine Study. Nutrition Reviews, 52(3), 84-94.

Swali, A., McMullen, S., Hayes, H., Gambling, L., McArdle, H. J., \& Langley-Evans, S. C. (2011). Cell cycle regulation and cytoskeletal remodeling are critical processes in the nutritional programming of embryonic development. PLoS One, 6, e23189.

Swinburn, B., Sacks, G., Hall, K. D., McPherson, K., Finegood, D. T., Moodie, M. L., et al. (2011). The global obesity pandemic: Shaped by global drivers and local environments. The Lancet, 378(9793), 804-814.
Tanner, J. M. (1981). A history of the study of human growth. New York: Cambridge University Press.

Taveras, E. M., Rifas-Shiman, S. L., Sherry, B., Oken, E., Haines, J. L., Kleinman, K., et al. (2011). Crossing growth percentiles in infancy and risk of obesity in childhood. Archives of Pediatrics and Adolescent Medicine, 165(11), 993-998.

Thame, M., Osmond, C., \& Trotman, H. (2012). Fetal growth and birth size is associated with maternal anthropometry and body composition. Maternal \& Child Nutrition. doi:10.1111/mcn.12027.

Theriot, C. M., Koenigsknecht, M. J., Carlson, P. E. J., Hatton, G. E., Nelson, A. M., Li, B., et al. (2014). Antibiotic-induced shifts in the mouse gut microbiome and metabolome increase susceptibility to Clostridium difficile infection. Nature Communications, 5, 3114.

Thompson, L. M., Bruce, N., Eskenazi, B., Diaz, A., Pope, D., \& Smith, K. R. (2011). Impact of reduced maternal exposures to wood smoke from an introduced chimney stove on newborn birth weight in rural Guatemala. Environmental Health Perspectives, 119(10), 1489-1494.

Thompson, A. L., Monteagudo-Mera, A., Cadenas, M. B., Lampl, M. L., \& Azcarate-Peril, M. A. (2015). Milkand solid-feeding practices and daycare attendance are associated with differences in bacterial diversity, predominant communities, and metabolic and immune function of the infant gut microbiome. Frontiers in Cellular and Infection Microbiology, 5(3), 1-15.

Thornburg, K. (2004). Fetal origins of cardiovascular disease. NeoReviews, 5(12), e527-e533.

Thornburg, K., Jonker, S., O'Tierney, P., Chattergoon, N., Louey, S., Faber, J., et al. (2011). Regulation of the cardiomyocyte population in the developing heart. Progress in Biophysics and Molecular Biology, 106(1), 289-299.

Tu, Y. K., West, R., Ellison, G. T., \& Gilthorpe, M. S. (2005). Why evidence for the fetal origins of adult disease might be a statistical artifact: The "reversal paradox" for the relation between birth weight and blood pressure in later life. American Journal of Epidemiology, 161(1), 27-32.

Turnbaugh, P. J., \& Gordon, J. I. (2009). The core gut microbiome, energy balance and obesity. Journal of Physiology, 587(17), 4153-4158.

Turnbaugh, P. J., Hamady, M., Yatsunenko, T., Cantarel, B. L., Duncan, A., Ley, R. E., et al. (2009). A core gut microbiome in obese and lean twins. Nature, 457(7228), 480-484.

Turnbaugh, P. J., Quince, C., Faith, J. J., McHardy, A. C., Yatsunenko, T., Niazi, F., et al. (2010). Organismal, genetic, and transcriptional variation in the deeply sequenced gut microbiomes of identical twins. Proceedings of the National Academy of Sciences, 107(16), 7503-7508.

Unger, C., Weiser, J. K., McCullough, R. E., Keefer, S., \& Grindlay Moore, L. (1988). Altitude, low birth weight, and infant mortality in Colorado. Journal of the American Medical Association, 259(23), 3427-3432. 
UNICEF. (2014). The state of the world's children 2015: Reimagine the future: Innovation for every child. Department of communication. New York: United Nations Children's Fund.

van Abeelen, A. F. M., Elias, S. G., Bossuyt, P. M. M., Grobbee, D. E., van der Schouw, Y. T., Roseboom, T. J., et al. (2012a). Famine exposure in the young and the risk of type 2 diabetes in adulthood. Diabetes, 61(9), 2255-2260.

van Abeelen, A. F. M., Veenendaal, M. V. E., Painter, R. C., de Rooij, S. R., Dijkgraaf, M. G. W., Bossuyt, P. M. M., et al. (2012b). Survival effects of prenatal famine exposure. American Journal of Clinical Nutrition, 95(1), 179-183.

Vazir, S., Engle, P., Balakrishna, N., Griffiths, P. L., Johnson, S. L., Creed-Kanashiro, H., et al. (2013). Clusterrandomized trial on complementary and responsive feeding education to caregivers found improved dietary intake, growth and development among rural Indian toddlers. Maternal \& Child Nutrition, 9(1), 99-117.

Vickaryous, N., \& Whitelaw, E. (2005). The role of early embryonic environment on epigeotype and phenotype. Reproduction, Fertility, and Development, 17(3), 335-340.

Victora, C., Morris, S., Barros, F., Horta, B., Weiderpass, E., \& Tomasi, E. (1998). Breastfeeding and growth in Brazilian infants. American Journal of Clinical Nutrition, 67(3), 452-458.

Wadhwa, P. D., Sandman, C.A., Porto, M., Dunkel-Schetter, C., \& Garite, T. J. (1993). The association between prenatal stress and infant birth weight and gestational age at birth: A prospective study. American Journal of Obstetrics and Gynecology, 169(4), 858-865.

Waterland, R. A., Lin, J. R., Smith, C. A., \& Jirtle, R. L. (2006). Post-weaning diet affects genomic imprinting at the insulin-like growth factor 2 (Igf2) locus. Human Molecular Genetics, 15(5), 705-716.

Weinberg, C. R. (2005). Invited commentary: Barker meets Simpson. American Journal of Epidemiology, 161(1), 33-35.

WHO MGRS. (2006). WHO child growth standards: Length/height-for-age, weight-for-age, weight-forlength, weight-for-height and body mass index-forage: Methods and development. Geneva: World Health Organization.

Wiedmeier, J. E., Joss-Moore, L. A., Lane, R. H., \& Neu, J. (2011). Early postnatal nutrition and programming of the preterm neonate. Nutrition Reviews, 69(2), 76-82.

Wijnstok, N. J., Hoekstra, T., van Mechelen, W., Kemper, H. C. G., \& Twisk, J. W. R. (2013). Cohort profile: The Amsterdam Growth and Health Longitudinal Study. International Journal of Epidemiology, 42(2), 422-429.

Wikoff, W. R., Anfora, A. T., Liu, J., Schultz, P. G., Lesley, S. A., Peters, E. C., et al. (2009). Metabolomics analysis reveals large effects of gut microflora on mammalian blood metabolites. Proceedings of the National Academy of Sciences, 106(10), 3698-3703.

Wiley, A. S. (1994). Neonatal and maternal anthropometric characteristics in a high-altitude population of the western Himalaya. American Journal of Human Biology, 6(4), 499-510.

Wilkinson, R., \& Marmot, M. (Eds.). (2003). Social determinants of health: The solid facts (2nd ed.). Copenhagen: World Health Organization.

Wilkinson, R. G., \& Pickett, K. E. (2006). Income inequality and population health: A review and explanation of the evidence. Social Science \& Medicine, 62(7), 1768-1784.

Wit, J. M., \& Camacho-Hubner, C. (2011). Endocrine regulation of longitudinal bone growth. Endocrine Development, 21, 30-41.

Worthman, C. (2009). Habits of the heart: Life history and the developmental neuroendocrinology of emotion. American Journal of Human Biology, 21(6), 772-781.

Worthman, C. M., \& Panter-Brick, C. (2008). Homeless street children in Nepal: Use of allostatic load to assess the burden of childhood adversity. Development and Psychopathology, 20(1), 233-255.

Yajnik, C. S., Fall, C. H. D., Coyaji, K. J., Hirve, S. S., Rao, S., Barker, D. J. P., et al. (2003). Neonatal anthropometry: The thin-fat Indian baby. The Pune Maternal Nutrition Study. International Journal of Obesity, 27(2), 173-180.

Yanagida, M., Ikai, N., Shimanuki, M., \& Sajiki, K. (2011). Nutrient limitations alter cell division control and chromosome segregation through growth-related kinases and phosphatases. Philosophical Transactions of the Royal Society of London B, Biological Sciences, 366, 3508-3520.

Zemel, B. S. (2012). Body composition during growth and development. In N. Cameron \& B. Bogin (Eds.), Human growth and development (2nd ed., pp. 461486). New York: Academic Press.

Open Access This chapter is licensed under the terms of the Creative Commons Attribution 4.0 International License (http://creativecommons.org/licenses/by/4.0/), which permits use, sharing, adaptation, distribution and reproduction in any medium or format, as long as you give appropriate credit to the original author(s) and the source, provide a link to the Creative Commons license and indicate if changes were made.

The images or other third party material in this chapter are included in the chapter's Creative Commons license, unless indicated otherwise in a credit line to the material. If material is not included in the chapter's Creative Commons license and your intended use is not permitted by statutory regulation or exceeds the permitted use, you will need to obtain permission directly from the copyright holder. 